\title{
Hydrogeology of the Owego-Apalachin Elementary School Geothermal Fields, Tioga County, New York
}

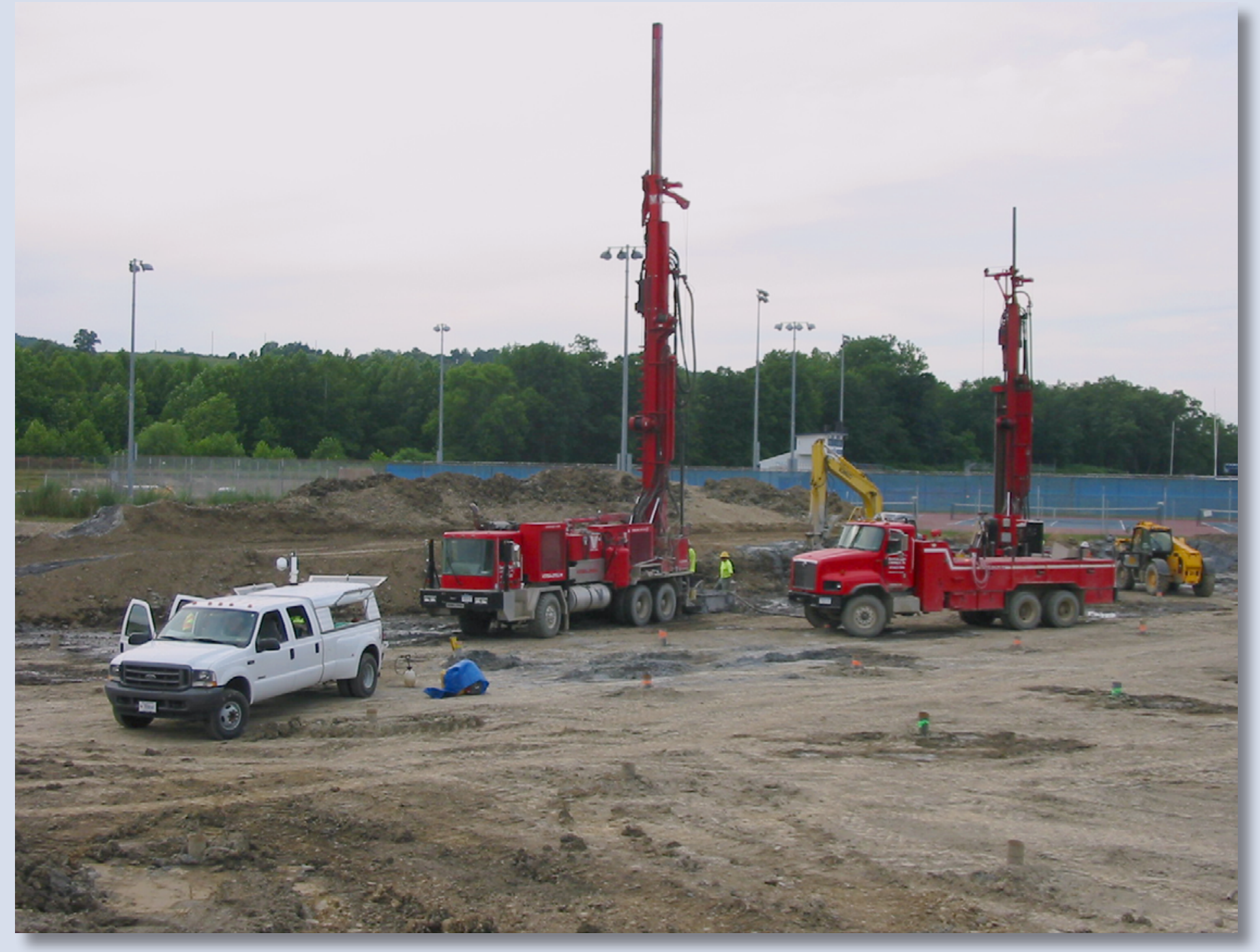

Scientific Investigations Report 2015-5155 
Cover. Hydraulic-rotary and air-percussion drilling rigs and geophysical logging truck during construction and data collection at the Owego-Apalachin Elementary School geothermal fields, Tioga County, New York, August 11, 2014. Photograph by John H. Williams, U.S. Geological Survey 


\section{Hydrogeology of the Owego-Apalachin Elementary School Geothermal Fields, Tioga County, New York}

By John H. Williams and William M. Kappel

Scientific Investigations Report 2015-5155 


\section{U.S. Department of the Interior SALLY JEWELL, Secretary}

\section{U.S. Geological Survey Suzette M. Kimball, Director}

\section{U.S. Geological Survey, Reston, Virginia: 2015}

For more information on the USGS - the Federal source for science about the Earth, its natural and living resources, natural hazards, and the environment-visit http://www.usgs.gov/ or call 1-888-ASK-USGS.

For an overview of USGS information products, including maps, imagery, and publications, visit http://www.usgs.gov/pubprod/.

Any use of trade, firm, or product names is for descriptive purposes only and does not imply endorsement by the U.S. Government.

Although this information product, for the most part, is in the public domain, it also may contain copyrighted materials as noted in the text. Permission to reproduce copyrighted items must be secured from the copyright owner.

Suggested citation:

Williams, J.H., and Kappel, W.M., 2015, Hydrogeology of the Owego-Apalachin Elementary School geothermal fields, Tioga County, New York: U.S. Geological Survey Scientific Investigations Report 2015-5155, 29 p., BQFGYFए http://dx.doi.org/10.3133/sir20155155.

ISSN 2328-0328 (online) 


\section{Acknowledgments}

The authors thank the Owego-Apalachin School District for site access during the construction of the geothermal fields. We also thank Paul Kirk, project manager for Lend Lease Corporation Limited, who coordinated the geothermal drilling activities and hydrogeologic data collection. We are grateful for the cooperation of Rocky Baye and the drilling crew from the American Auger and Ditch Company, and Timothy Bechtel, Robert Krause, and the site hydrogeologists from Enviroscan, Inc. We also acknowledge the Toxics Hydrology Program of the U.S. Geological Survey for providing funding. 



\section{Contents}

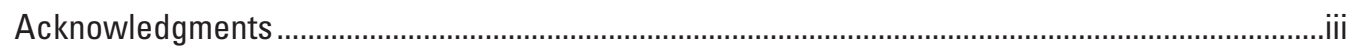

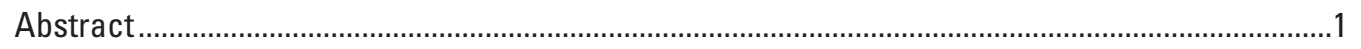

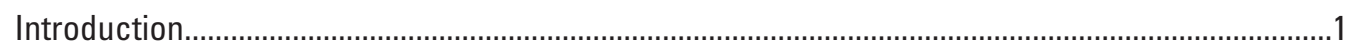

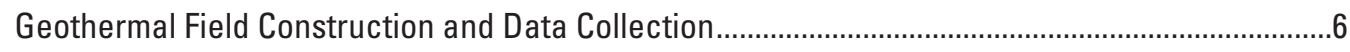

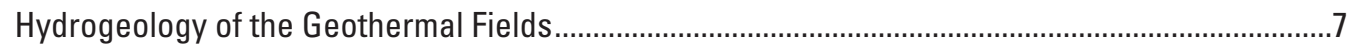

Lithology, Bedding, and Fractures .....................................................................................

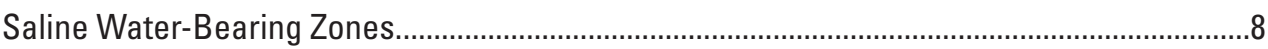

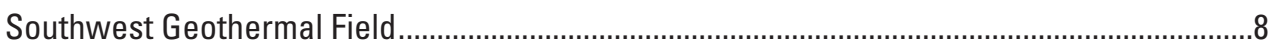

Northeast Geothermal Field .............................................................................................18

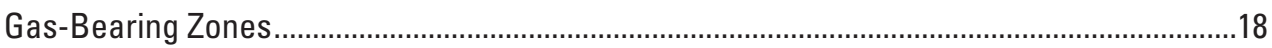

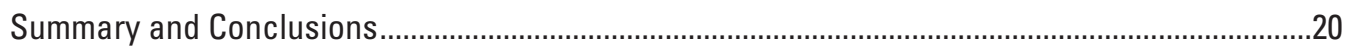

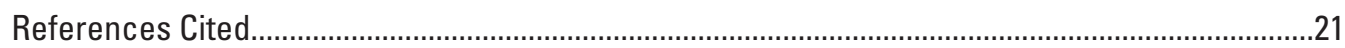

Appendix 1. Video of Local News Report about Methane Fire During Drilling of Borehole A9 at the Owego-Apalachin Elementary School Geothermal Fields, Tioga County, New York.

Appendix 2. Location, Construction, and Hydrogeologic Information for Selected Boreholes and Wells at and near the Owego-Apalachin Elementary School Geothermal Fields, Tioga County, New York

Appendix 3. Field and Laboratory Chemical Analyses of Water and Gas Samples from Boreholes A9 and 01 at the Owego-Apalachin Elementary School Geothermal Fields, Tioga County, New York

Appendix 4. Video of the Unloading of Methane Gas and Water from Borehole A12 at the Owego-Apalachin Elementary School Geothermal Fields, Tioga County, New York

\section{Figures}

1. Map showing location of the Owego-Apalachin Elementary and Middle-High School geothermal fields, Town of Owego production wells, and surficial geology at Owego, Tioga County, New York

2. Satellite image showing location of the Owego-Apalachin Elementary School and Middle-High School geothermal fields and selected boreholes at Owego, Tioga County, New York.

3. Geologic section of the Owego Creek valley fill and surrounding bedrock uplands at the Owego-Apalachin Elementary School geothermal fields, Tioga County, New York

4. Map showing location of boreholes from which geophysical logs, water levels, and specific-depth water-chemistry samples were collected at the OwegoApalachin Elementary School geothermal fields, Tioga County, New York.

5. Gamma logs of boreholes $01, \mathrm{~A} 12$, and R15 and generalized lithology identified as sandstone-rich and shale-rich based on relative gamma log response of the upper Devonian bedrock at the Owego-Apalachin Elementary School geothermal fields, Tioga County, New York 
6. Gamma, electromagnetic-conductivity, temperature, specific conductance, and flow logs and generalized lithology, bedding, fractures, and water- and gas-bearing zones in $A$, borehole 01 and $B$, borehole $A 9$ at the Owego-Apalachin Elementary School southwest geothermal field, Tioga County, New York

7. Optical- and acoustic-televiewer images of $A$, a freshwater-bearing fractured zone in borehole $01, B$, a saline water-bearing fractured zone in borehole 01 , and $C$, a saline water-bearing fractured zone in borehole $A 9$ at the Owego-Apalachin Elementary School southwest geothermal field, Tioga County, New York

8. Graphs showing altitude and depth from land surface of saline water-bearing fractured zones reported by the driller or delineated through geophysical-log analysis in boreholes at the Owego-Apalachin Elementary School geothermal fields, Tioga County, New York

9. Gamma, caliper, electromagnetic-conductivity, and specific-conductance logs, showing relative log response, and saline water-bearing fractured zones reported by the driller in selected boreholes at the Owego-Apalachin Elementary School geothermal fields, Tioga County, New York: $A$, borehole $\mathrm{A} 1$ to borehole A9; $B$, borehole 01 to borehole $010 ; C$, borehole $\mathrm{A} 9$ to borehole $\mathrm{K} 9 ; \mathrm{D}$, borehole $\mathrm{K} 9$ to borehole 010 ; $E$, borehole R15 to borehole R21; and $F$, borehole R15 to Y17.

10. Graph showing water-level altitude in borehole A9 during hydraulic drilling and methane-gas unloading of borehole 01 at the Owego-Apalachin Elementary School geothermal fields, Tioga County, New York, April 4, 2014.

11. Graphs showing water-level change in response to wastewater injections into borehole $\mathrm{A} 9$ and Theis analysis match in $A$, borehole $\mathrm{K} 9$ and $B$, borehole $\mathrm{A} 1$ at the Owego-Apalachin Elementary School geothermal fields, Tioga County, New York, August 11, 2014...

12. Graph showing chloride and chloride/bromide ratios for mixing of freshwater with deicing salt and with formation brine from oil and gas fields, selected groundwater samples from northeastern Pennsylvania, and saline-water samples from boreholes A9 and 01 at the Owego-Apalachin Elementary School geothermal fields, Tioga County, New York.

13. Graphs showing occurrence of methane-gas discharge at land surface during and following drilling of boreholes, as reported by the driller/consultant at the OwegoApalachin Elementary School geothermal fields, Tioga County, New York

14. Graph showing stable-isotopic composition of carbon and hydrogen in methane in upper Devonian bedrock groundwater samples from water wells in south-central New York; water wells, a salt spring, and a test hole in northeastern Pennsylvania; and borehole A9 at the Owego-Apalachin Elementary School geothermal fields, Tioga County, New York

\section{Table}

1. Depth, date, and type of hydrogeologic data collection from selected boreholes at the Owego-Apalachin Elementary School geothermal fields, Tioga County, New York 


\title{
Conversion Factors
}

Inch/Pound to SI

\begin{tabular}{lll}
\hline \multicolumn{1}{c}{ Multiply } & By & \multicolumn{1}{c}{ To obtain } \\
\hline inch & Length & \\
foot (ft) & 2.54 & centimeter $(\mathrm{cm})$ \\
mile (mi) & 0.3048 & meter $(\mathrm{m})$ \\
& 1.609 & kilometer $(\mathrm{km})$ \\
\hline gallon (gal) & Volume & \\
\hline & 3.785 & liter $(\mathrm{L})$ \\
\hline gallon per minute $(\mathrm{gal} / \mathrm{min})$ & Flow rate & \\
\hline & 0.06309 & liter per second $(\mathrm{L} / \mathrm{s})$ \\
\hline feet squared per day $\left(\mathrm{ft}^{2} / \mathrm{d}\right)$ & Transmissivity & \\
\hline
\end{tabular}

Temperature in degrees Celsius $\left({ }^{\circ} \mathrm{C}\right)$ is converted to degrees Fahrenheit $\left({ }^{\circ} \mathrm{F}\right)$ as follows:

${ }^{\circ} \mathrm{F}=\left(1.8 x^{\circ} \mathrm{C}\right)+32$

Vertical coordinate information is referenced to the North American Vertical Datum of 1988

(NAVD 88). [In this report this datum is also referred to as "above mean sea level" (asl)]

Horizontal coordinate information is referenced to the North American Datum of 1983 (NAD 83).

Altitude, as used in this report, refers to distance above the vertical datum.

Specific conductance is given in microsiemens per centimeter at 25 degrees Celsius $(\mu \mathrm{S} / \mathrm{cm}$ at $\left.25^{\circ} \mathrm{C}\right)$.

\section{Other abbreviations in this report:}

\author{
CPS counts per second \\ $\mathrm{ft}$ asl feet above sea level \\ $\mathrm{ft}$ bls feet below land surface \\ OACSD Owego-Apalachin Central School District \\ OAES Owego-Apalachin Elementary School
}





\title{
Hydrogeology of the Owego-Apalachin Elementary School Geothermal Fields, Tioga County, New York
}

\author{
By John H. Williams and William M. Kappel
}

\section{Abstract}

The hydrogeology of the Owego-Apalachin Elementary School geothermal fields, which penetrate saline water and methane in fractured upper Devonian age bedrock in the Owego Creek valley, south-central New York, was characterized through the analysis of drilling and geophysical logs, water-level monitoring data, and specificdepth water samples. Hydrogeologic insights gained during the study proved beneficial for the design of the geothermal drilling program and protection of the overlying aquifer during construction, and may be useful for the development of future geothermal fields and other energyrelated activities, such as drilling for oil and natural gas in similar fractured-bedrock settings.

The southwest geothermal field consists of 204 closedloop wells that penetrate a major saline water-bearing zone associated with bedding-plane fractures near the middle of an interbedded sandstone and shale interval at depths of 238 to 263 feet below land surface (ft bls). The northeast geothermal field consists of 80 closed-loop wells that penetrate a major saline water-bearing zone associated with bedding-plane fractures near the base of the interbedded sandstone and shale interval at depths of 303 to $323 \mathrm{ft}$ bls.

Transmissivity estimates for the major saline waterbearing fractured zones range from 735 to 3,400 feet squared per day. The saline water-bearing zone in the southwest field is hydraulically connected over a horizontal distance of at least 350 feet. The hydraulic connection between subhorizontal, stacked bedding-plane fractures is limited by the number and transmissivity of interspersed higher angle fractures; locally, greater stratigraphic separation results in reduced connectivity to a greater degree than does horizontal distance.

The specific conductance of the saline water from the shallower fractured zone in the southwest field was about 16,000 microsiemens per centimeter at 25 degrees Celsius $\left(\mu \mathrm{S} / \mathrm{cm}\right.$ at $\left.25^{\circ} \mathrm{C}\right)$, and that from the fractured zone in the northeast field was about $65,000 \mu \mathrm{S} / \mathrm{cm}$ at $25^{\circ} \mathrm{C}$. The saline waters were characterized by a chemical composition similar to that of deep formation brines collected from oil and gas wells in the Appalachian Basin. About 40 percent of the geothermal wells discharged methane gas to land surface during and (or) following drilling. Sandstone beds at depths of 348 to $378 \mathrm{ft}$ bls are the likely source of the methane gas, which was determined to be early thermogenic in origin.

\section{Introduction}

During September 7-11, 2011, flooding associated with the remnants of Tropical Storm Lee caused major property losses in south-central New York. The OwegoApalachin Elementary School (OAES) in the Town of Owego, Tioga County, New York, (figs. 1 and 2) was heavily damaged. Following assessment of the damage, the OwegoApalachin Central School District (OACSD) decided to rebuild the elementary school at the same location but at a higher elevation. A closed-loop geothermal system was selected as the source for heating and cooling of the new elementary school.

The closed-loop geothermal system for the OAES consists of two geothermal fields within the Owego Creek valley (figs. 1 and 2). The OAES geothermal fields are arrayed in two rectangular grids. The southwest geothermal field consists of 204 boreholes, and the northeast field consists of 80 boreholes. The boreholes are spaced 20 feet (ft) apart, cased through the valley-fill deposits, and completed in bedrock at a depth of 495 feet below land surface (ft bls). The land surface gently slopes toward Owego Creek from 815 feet above sea level ( $\mathrm{ft}$ asl) at eastern edge of the northeast field to $812.5 \mathrm{ft}$ asl at the western edge of the southwest field.

As described by Reynolds and Garry (1990), the Owego Creek and Susquehanna River valleys at Owego are underlain by alluvial, glaciofluvial, glaciolacustrine, and till deposits (fig. 1). In the OAES geothermal fields, the valleyfill sediments are about $130 \mathrm{ft}$ thick, most of which are variably silty sand and gravel deposits of glaciofluvial origin (fig. 3). Upper Devonian sedimentary bedrock underlies the valley fill and is mantled by till in the surrounding uplands. The sedimentary bedrock is folded into broad anticlines and synclines in south-central New York. Owego is on the north limb of the Elmira Anticline and the south limb of the Horseheads Syncline. The axial traces of the anticlinal and synclinal structures locally trend east-west. The bedrock strata generally dip about 30 feet per mile ( $\mathrm{ft} / \mathrm{mi}$ ) to the north in the Owego area (Wedel, 1932). 


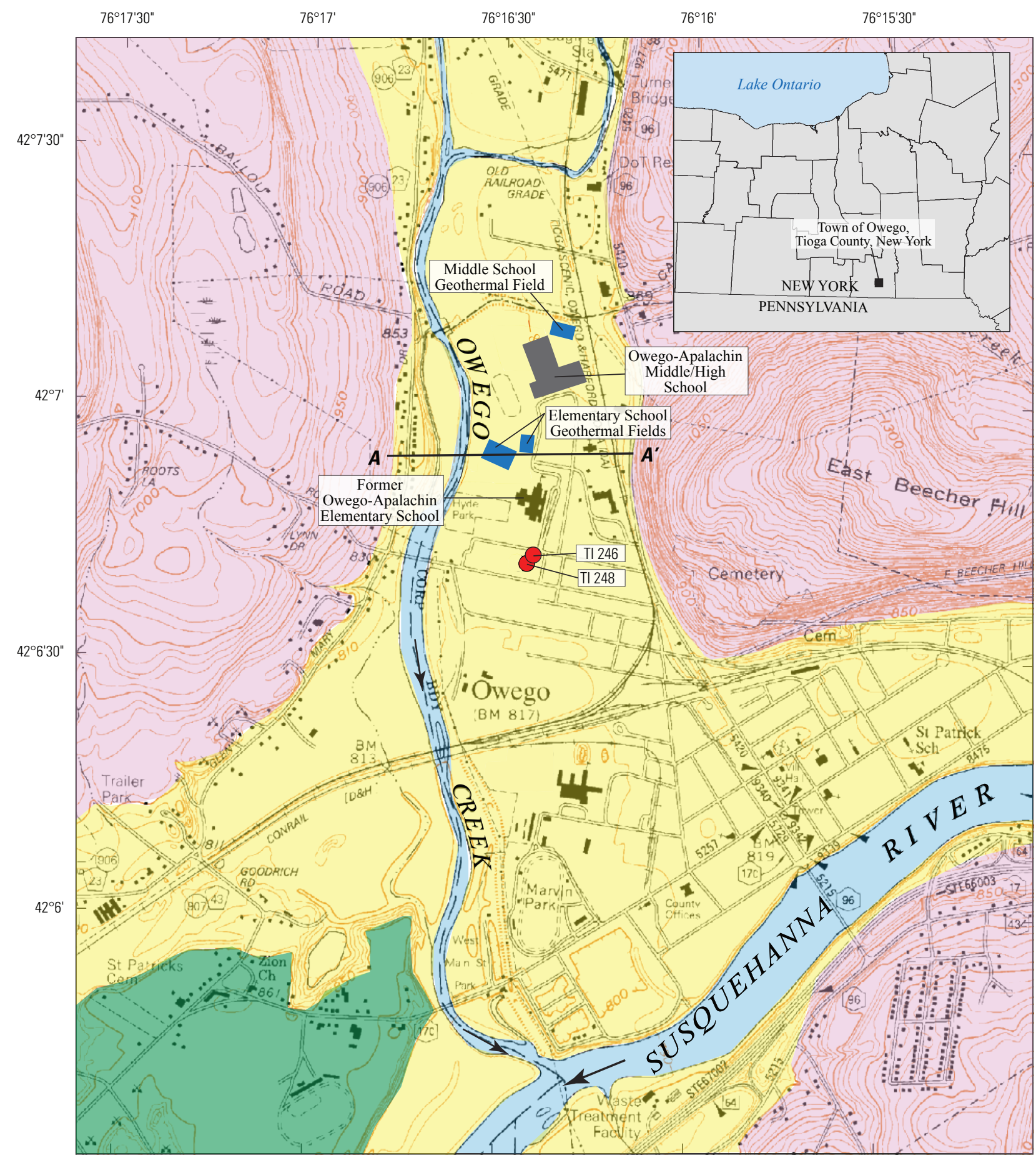

Base from The New York State Department of Transportation, accessed in 2015 at https://gis.ny.gov/gisdata/ Universal Transverse Mercator projection, Zone 18

\section{EXPLANATION}

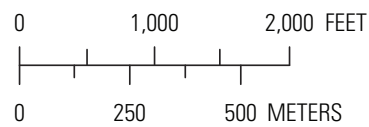

Alluvial and glaciofluvial deposits

Glaciofluvial over glaciolacustrine deposits

Till over bedrock

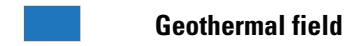

TI 246

Production well and identification number assigned by the U.S. Geological Survey

\section{$A-A^{\prime} \quad$ Line of geologic section shown}

Figure 1. Location of the Owego-Apalachin Elementary and Middle-High School geothermal fields, Town of Owego production wells, and surficial geology at Owego, Tioga County, New York. Surficial geology is modified from Reynolds and Garry (1990). (Section $A-A^{\prime}$ is shown in figure 3.) 


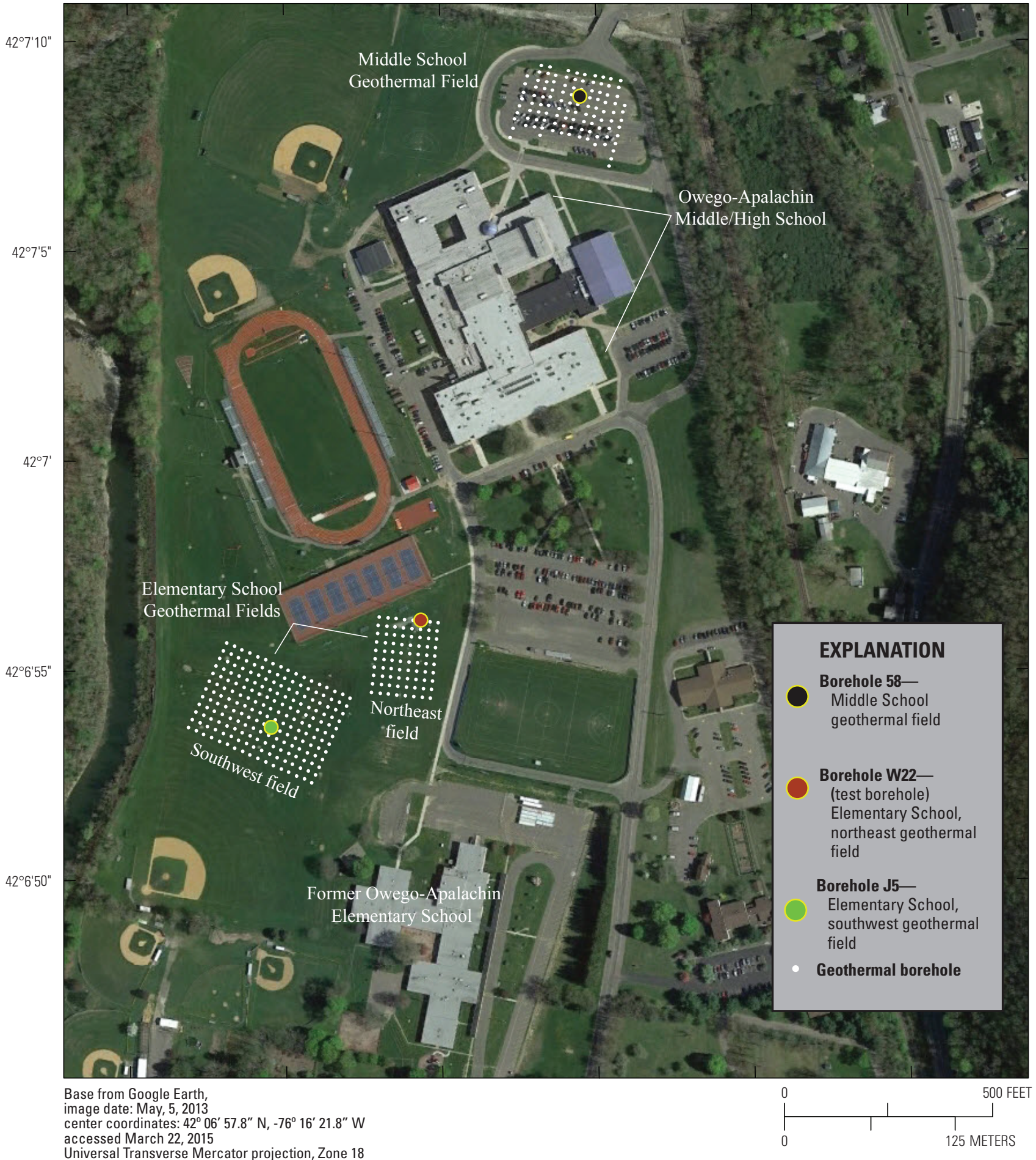

Figure 2. Location of the Owego-Apalachin Elementary School and Middle-High School geothermal fields and selected boreholes at Owego, Tioga County, New York. 


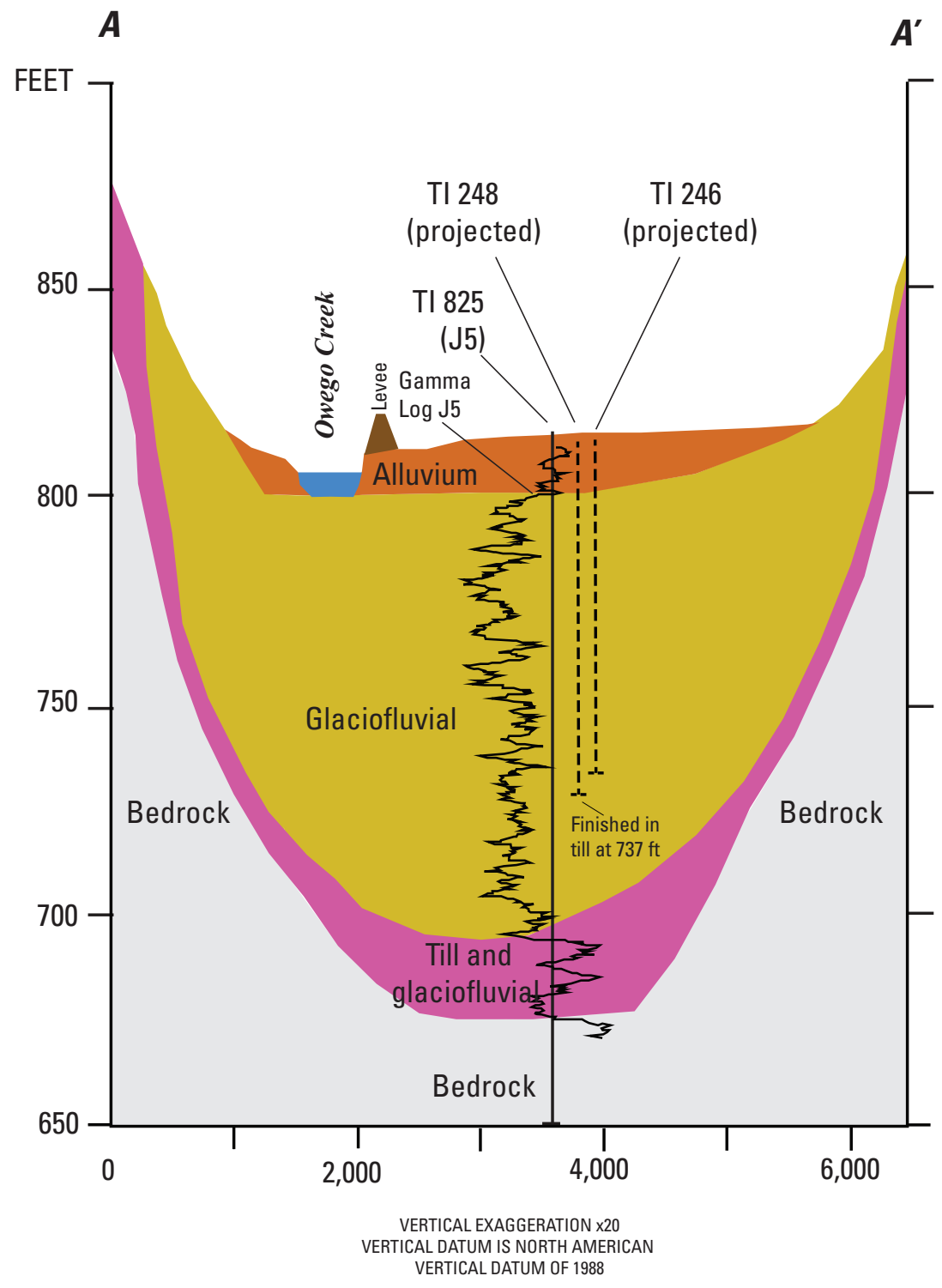

Figure 3. Geologic section of the Owego Creek valley fill and surrounding bedrock uplands at the Owego-Apalachin Elementary School geothermal fields, Tioga County, New York. (Line of section $A-A^{\prime}$ is shown in figure 1)
In April 2013, a 495-ft deep test borehole (borehole W22, fig. 2) was drilled at the northern edge of the northeast OAES geothermal field. The drilling log obtained for the test hole contains little information on hydrogeologic conditions encountered in the valley fill and bedrock and no report of saline water or gas. However, photographs taken during drilling reportedly show foamy discharge typical of saline water. Drilling logs for the Owego Middle School geothermal field (fig. 2), which was constructed in 2004 and consists of 108 closed-loop boreholes that are $405 \mathrm{ft}$ deep, contained some description of the valley fill but very little information on hydrogeologic conditions encountered in the bedrock and no report of saline water or gas.

Construction of the southwest OAES geothermal field began during the winter of 2013-14 with installation of surface casings through the valley fill and into the top of bedrock. On February 10, 2014, during drilling of the first borehole (borehole A9, fig. 4) into the bedrock, a major fractured zone bearing saline water was penetrated at $260 \mathrm{ft}$ bls. As drilling continued to $380 \mathrm{ft}$ bls, methane gas was penetrated that caused the water-filled borehole to unload (forcefully discharge) both saline water and gas to the land surface for more than 4 hours. The methane gas ignited, catching the drilling rig on fire and causing substantial damage to the rig (see appendix 1 for video of local news report about the drilling rig fire).

Given the presence of saline water and methane gas at the field site, hydrogeologic information was needed to develop a plan for the drilling and completion of the OAES geothermal boreholes with specific protocols to protect human health and property, as well as the local groundwater resources. Protection of the water supply for the Town of Owego was a paramount consideration in the development of the plan. The town's water is supplied by two nearby production wells that draw from the overlying glaciofluvial sand-and-gravel aquifer (figs. 1 and 3) (Randall, 1972; Reynolds and Garry, 1990). 


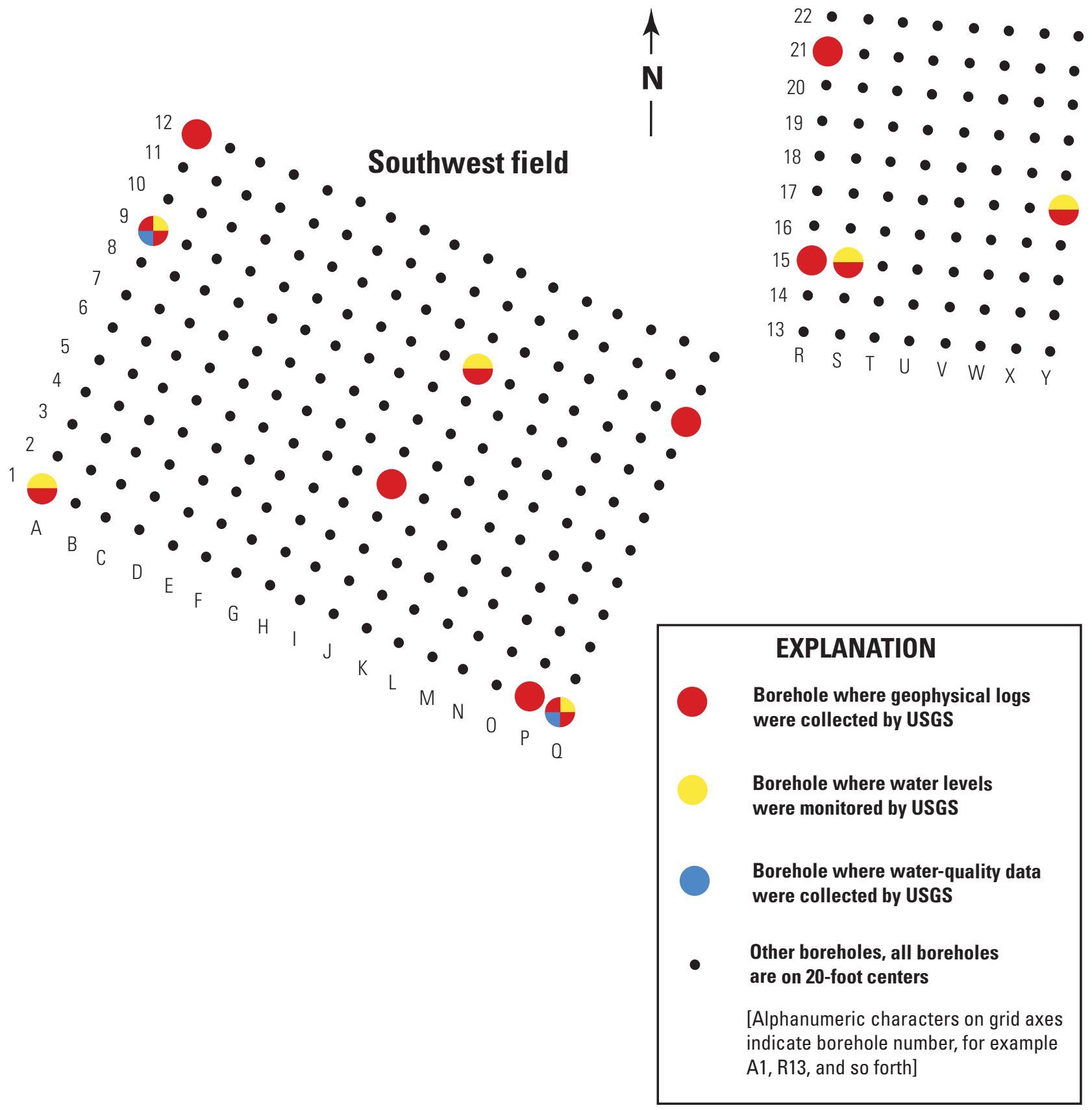

Figure 4. Location of boreholes from which geophysical logs, water levels, and specific-depth water-chemistry samples were collected at the Owego-Apalachin Elementary School geothermal fields, Tioga County, New York. (USGS, U.S. Geological Survey) 
The U.S. Geological Survey (USGS) recognized that this field site provided a unique opportunity to collect and analyze detailed hydrogeologic information that would (1) demonstrate the integrated application of borehole-logging methods in the efficient and environmentally sound development of geothermal fields in a challenging and complex setting and (2) advance the understanding of the occurrence of saline water and methane in fractured upper Devonian bedrock. The study complements the borehole characterization work by Risser and others (2013) in north-central Pennsylvania, an area of active Marcellus shale gas development.

This report presents the hydrogeologic characterization of the OAES geothermal fields. The characterization methods are presented, and integration of the results with the geothermalborehole drilling plans and construction are discussed. The hydrogeologic information is presented in tables, log composites, maps, and sections. This report could provide useful information for the development of geothermal fields and other energy-related activities, such as drilling for oil and natural gas, in similar fractured-bedrock settings.

\section{Geothermal Field Construction and Data Collection}

Collection of hydrogeologic data by the USGS was an integral part of the construction of the OAES geothermal fields, prior to and during the full-scale borehole drilling program. The USGS collected geophysical logs from the first bedrock borehole drilled below the surface casing to a temporary completion depth of $380 \mathrm{ft}$ bls (borehole A9, fig. 4) as a preliminary step in characterizing hydrogeologic conditions at the geothermal fields. To provide additional hydrogeologic information prior to the onset of the full-scale drilling program, the OACSD contractors drilled a 495-ft deep test borehole in the southeastern corner (borehole Q1, fig. 4) and one in the northwestern corner (borehole A12, fig. 4) of the OAES southwest field. During drilling of these boreholes, specific conductance and methane concentrations of the drilling discharge were monitored, and penetration of waterbearing fractures was noted. Water levels were monitored using a pressure transducer in borehole A9 during the drilling of borehole Q1. Following their completion, geophysical logs were collected from boreholes Q1 and A12.

On the basis of the hydrogeologic data collected by the USGS from boreholes A9, Q1, and A12 and discussions with the USGS and New York State Department of Environmental Conservation, the OACSD construction-site manager, driller, and consultants developed a comprehensive plan for the drilling and completion of the geothermal boreholes. The plan (Enviroscan, Incorporated, 2014) consisted of eight key components.

1. Drill an 8-inch diameter hole to a minimum of $10 \mathrm{ft}$ into competent bedrock, position the 6-inch-diameter surface casing into the bedrock socket leaving about $3 \mathrm{ft}$ of open hole, insert a packer with grout pipe penetration and inflate the packer to isolate the bottom several feet of casing and underlying open hole, pressure grout the interval below the packer, deflate and pull the packer, and allow grout to cure for minimum 24 hours.

2. Drill through the grout plug, and continue drilling a 6-inch-diameter hole.

3. Periodically monitor the specific conductance of the produced water during drilling.

4. Direct all drilling discharge through a diverter into a sealed roll-off box that contains two steel baffles to capture drill cuttings and a final chamber to hold the clarified produced water.

5. Inject collected saline water from the roll-off box into an uncompleted borehole that is open to a saline waterbearing zone.

6. Continue drilling past the major saline water-bearing zone, and once past the zone, position a set of tightfitting K-packers (steel couplings each with three stiff, rubber-like ribs slightly larger than the diameter of the drilled hole in bedrock) threaded on both ends of a 20 -foot length of 5-inch-diameter casing so that packers are positioned above and below the zone; adjust the depth of drilling and position of the packers on the basis of drilling and geophysical logs from adjacent boreholes.

7. Drill a 5-inch-diameter hole to the total borehole depth of $495 \mathrm{ft}$ bls, and insert geothermal loop tubing and grout as soon as possible.

8. Continuously monitor ambient air with a combustible gas indicator set to alarm at 10 percent Lower Explosive Limit of methane gas; shut down drilling rig and other combustion sources if alarm sounds and evacuate crew upwind until the alarm ceases.

During the full-scale geothermal drilling program, the USGS collected geophysical logs from five additional boreholes in the southwest field and four boreholes in the northeast field. Description of the geophysical log types indicated in table 1 and their application in hydrogeologic investigations are discussed in Keys (1990), Rider and Kennedy (2011), and Risser and others (2013). Groundwater levels were monitored in four boreholes in the southwest field and two boreholes in the northeast field using pressure transducers during selected drilling and drilling-wastewater injection activities. Water samples were collected for field measurement of specific conductance with a down-hole point sampler at specific depths from three boreholes (A9, A12, and Y17). The water samples from two of those boreholes (A9 and A12) were submitted to the USGS National WaterQuality Laboratory, Denver, Colorado, for chemical analysis of selected ions and trace elements, and one methane gas 
Table 1. Depth, date, and type of hydrogeologic data collection from selected boreholes at the Owego-Apalachin Elementary School geothermal fields, Tioga County, New York.

[----- indicates no data]

\begin{tabular}{|c|c|c|c|c|c|}
\hline $\begin{array}{l}\text { Geothermal } \\
\text { field borehole } \\
\text { number }\end{array}$ & $\begin{array}{c}\text { County } \\
\text { well } \\
\text { number }\end{array}$ & $\begin{array}{l}\text { Water and gas sample date, depth } \\
\text { (in feet below land surface), and type }\end{array}$ & Water-level monitoring date & $\begin{array}{l}\text { Borehole Ic } \\
\quad \text { (in feet }\end{array}$ & $\begin{array}{l}\text { g date, type', and depth } \\
\text { below land surface) }\end{array}$ \\
\hline A9 & TI 916 & $\begin{array}{l}3 / 4 / 2014 \\
100 \text { - Specific conductance } \\
340 \text { - Basic ions, trace metals, and isotopic } \\
\quad \text { content of methane }\end{array}$ & $\begin{array}{l}4 / 14 / 14 \text { and } \\
8 / 08-11 / 2014\end{array}$ & $\begin{array}{l}04 / 14 / 2014 \\
376\end{array}$ & $\begin{array}{l}\text { CT, ZF, AT, } \\
\text { OT, MI, ZM }\end{array}$ \\
\hline Q1 & TI 917 & $\begin{array}{l}\text { 4/23/2014 } \\
200 \text { and } 340 \text { - Bromide and chloride }\end{array}$ & $8 / 08-11 / 2014$ & $\begin{array}{l}04 / 14 / 2014 \\
495\end{array}$ & $\begin{array}{l}\text { CT, ZF, AT } \\
\text { OT, ZM }\end{array}$ \\
\hline A12 & TI 919 & ------- & ------ & $\begin{array}{l}04 / 14 / 2014 \\
495\end{array}$ & ZF, AT \\
\hline A1 & TI 922 & ------- & $8 / 08-11 / 2014$ & $\begin{array}{l}08 / 11 / 2014 \\
270\end{array}$ & CT, ZF, AT \\
\hline K9 & TI 923 & ------- & $8 / 08-11 / 2014$ & $\begin{array}{l}08 / 11 / 2014 \\
265\end{array}$ & $\mathrm{CT}, \mathrm{ZF}, \mathrm{AT}$ \\
\hline S15 & TI 924 & ------- & $8 / 08-11 / 2014$ & $\begin{array}{l}08 / 11 / 2014 \\
287 \mathrm{ft}\end{array}$ & $\mathrm{CT}, \mathrm{ZF}$ \\
\hline Y17 & TI 925 & $\begin{array}{l}8 / 11 / 2014 \\
305-\text { Specific conductance }\end{array}$ & $8 / 08-11 / 2014$ & $\begin{array}{l}08 / 11 / 2014 \\
240\end{array}$ & $\mathrm{CT}, \mathrm{ZF}, \mathrm{AT}$ \\
\hline R15 & TI 926 & ------- & ------ & $\begin{array}{l}08 / 11 / 2014 \\
495\end{array}$ & $\mathrm{CT}, \mathrm{ZF}, \mathrm{AT}$ \\
\hline R21 & TI 927 & ------- & ------- & $\begin{array}{l}08 / 11 / 2014 \\
310\end{array}$ & CT, ZF, AT \\
\hline P1 & TI 844 & ------- & ------- & $\begin{array}{l}09 / 18 / 2014 \\
495\end{array}$ & MI \\
\hline $\mathrm{J} 5$ & TI 825 & ------- & ------- & $\begin{array}{l}10 / 15 / 2014 \\
495\end{array}$ & $\begin{array}{l}\mathrm{CT}, \mathrm{ZF}, \mathrm{AT} \\
\mathrm{MI}\end{array}$ \\
\hline Q10 & TI 864 & ------- & ------ & $\begin{array}{l}10 / 15 / 2014 \\
310\end{array}$ & CT, ZF, AT \\
\hline
\end{tabular}

'Log type: AT, Acoustic televiewer; CT, Caliper; MI, Electromagnetic induction and gamma; OT, Optical televiewer; ZF, Gamma, fluid resistivity, temperature; and ZM, Electromagnetic flowmeter, fluid resistivity, temperature.

sample from A9 was submitted to the Isotech Laboratory, Champaign, Illinois, for analysis of the isotopic concentrations of carbon-13 and deuterium. Water-sample collection and preservation followed procedures described by the U.S. Geological Survey (variously dated). The locations of the geothermal boreholes from which geophysical logs, water levels, and specific-depth water samples were collected prior to and during the full-scale drilling program are presented in figure 4. Borehole depths and the date and type of data collection are presented in table 1.

Location and construction information on selected geothermal boreholes and wells are presented in appendix 2 and are available from the U.S. Geological Survey National Water Information System (NWIS) at http://waterdata.usgs. gov/nwis. The groundwater-level and water-chemistry data are available from NWIS at http://waterdata.usgs.gov/nwis. The geophysical logs are available in Log Ascii Standard (LAS) format and Portable Document Format (PDF) at the USGS New York Water Science Center Geophysical Log Archive at http:/ny.water.usgs.gov/maps/geologs/.

\section{Hydrogeology of the Geothermal Fields}

The hydrogeology of the OAES geothermal fields was characterized through the analysis of drilling and geophysical logs, water-level monitoring data, and specific-depth waterchemistry samples. Bedrock lithology, bedding and fracture distribution and orientation, and hydraulic and water-quality characteristics of fractured zones penetrated by the geothermal boreholes were determined. The character of the methanebearing zones penetrated by the geothermal boreholes also was evaluated. 


\section{Lithology, Bedding, and Fractures}

The OAES geothermal fields are underlain by very gently dipping clastic-sedimentary bedrock. The geothermal boreholes penetrate about $130 \mathrm{ft}$ of valley fill above the bedrock. The top of bedrock is a relatively flat surface at an altitude of about $680 \mathrm{ft}$ asl. Strata dominated by shale, sandstone, and interbedded intervals of both lithologies are shown on the gamma logs and appear to be continuous across the two fields (fig. 5). Some individual sandstone beds also appear to be continuous, although others pinch out between boreholes. Shale-rich intervals are present at about 330-385, 400-425, and 590-640 ft asl. Sandstone-rich intervals are present at about 385-400 and 425-465 ft asl. An interval of shale and some sandstone is present at about $465-505 \mathrm{ft}$ asl, and two intervals of sandstone with some shale are present at about 505-590 and 640-680 ft asl. Bedding planes delineated on the optical-televiewer logs of boreholes A9 and Q1 have an average dip of about 1.5 degrees and display a wide range of dip directions (fig. 6). The dip of the bedrock strata determined from six selected sandstone beds (dashed lines on fig. 5), correlated between boreholes Q1, A12, and R15 at altitudes between 390 and $640 \mathrm{ft}$ asl (figs. 4 and 5), is to the north-northeast at 0.5 to 1 degree, which is similar to that determined for the Owego area by Wedel (1932).

Fractures penetrated by the geothermal boreholes and imaged by the acoustic- and optical-televiewer logs generally are subhorizontal separations associated with bedding planes (figs. 6 and 7). Some higher angle fractures including subvertical fractures were intersected by the boreholes. Most fractures are penetrated between 500 and $570 \mathrm{ft}$ asl in the thicker interbedded sandstone and shale interval.

\section{Saline Water-Bearing Zones}

The OAES geothermal fields intersect major saline water-bearing fractured zones. Saline water-bearing fractures were identified during drilling of the boreholes by (1) "drillbit drops" or short intervals of increased drilling penetration rate, (2) increased rate of air-hammer drilling discharge, (3) loss of drilling water circulation, (4) foamy drillingwater discharge typical of saline water, and (5) specific conductance measurements of drilling discharge water. Saline water-bearing fractures were identified through geophysical logging in selected boreholes by (1) increased hole diameter on the caliper logs, (2) sharp increases in electromagnetic conductivity on the induction logs, (3) single or multiple planar features on oriented 360-degree images of the borehole wall on the acoustic- and optical-televiewer logs, (4) changes on the specific-conductance logs, and (5) changes in vertical flow rates on the flowmeter logs. Hydraulic connections and properties of the major fractured zones were determined by analysis of the water-level responses in selected boreholes during drilling and injection of drilling wastewater. The chemical composition of the saline waters was characterized through analysis of depth-specific samples from two boreholes.

\section{Southwest Geothermal Field}

In the southwest geothermal field, the boreholes generally intersect bedding-plane fractures associated with a major saline water-bearing zone near the middle of the thicker interbedded sandstone and shale interval, as shown in figure 6 . In the southern half of the field, the major saline waterbearing fractured zone generally is present at $560-575 \mathrm{ft}$ asl (253-238 ft bls) (appendix 2 and fig. 8). Farther to the northeast across the field, the major zone generally is at an altitude of 550-560 ft asl (263-253 ft bls).

The hydrogeologic sections aligned southwest-northeast from boreholes A1 to A9 (fig. 9A, in back of report) and from boreholes Q1 to Q10 (fig. 9B, in back of report) show that the major fractured zone generally is deeper in a northeastern direction and associated with stratigraphically lower beds in this field. The hydrogeologic section aligned northwestsoutheast from boreholes A9 to K9 (fig. 9C, in back of report) shows a relatively consistent altitude and stratigraphic position for the major saline water-bearing zone. The major saline water-bearing zone intersected by both boreholes A9 and K9 appears to be associated with fractures near the base of the same sandstone bed.

The saline water-bearing fractures are deepest in the northeastern corner of the southwest field generally ranging from 540 to $550 \mathrm{ft}$ asl (273 to $263 \mathrm{ft}$ bls) and appear to form a non-continuous fractured zone (fig. 8) in the northeastern part of the southwest field. The hydrogeologic sections from boreholes K9 to Q10 (fig. 9D, in back of report) and from boreholes Q1 to Q10 (fig. 9B, in back of report) show an increase in the vertical separation between the subhorizontal fractures toward the northeastern corner of the southwest field, which indicates a likely decrease in the hydraulic continuity of the saline fractured zone in this part of the field.

During drilling of borehole Q1 on April 4, 2014, waterbearing fractures were penetrated at $672 \mathrm{ft}$ asl $(141 \mathrm{ft}$ bls) just below the top of bedrock and the base of the surface casing (fig. 6A). These fractures produced more than 10 gallons per minute $(\mathrm{gal} / \mathrm{min})$ of freshwater with a specific conductance of 600 microsiemens per centimeter at 25 degrees Celsius $\left(\mu \mathrm{S} / \mathrm{cm}\right.$ at $25^{\circ} \mathrm{C}$ ) when briefly developed with compressed air prior to drilling the borehole deeper. The major saline water-bearing fractured zone was penetrated by the borehole at $561 \mathrm{ft}$ asl ( $252 \mathrm{ft}$ bls). This fractured zone produced $100 \mathrm{gal} / \mathrm{min}$ or more of saline water for a period of about 15 minutes ( $\mathrm{min}$ ) when methane gas from deeper in the borehole unloaded the borehole-water column.

A flowmeter log collected several days after borehole Q1 was drilled to its final depth of $495 \mathrm{ft}$ bls indicated there was about $3 \mathrm{gal} / \mathrm{min}$ of upward borehole flow from the major saline water-bearing zone into the freshwater-bearing zone (figs. 6A and 9B, in back of report). This upward flow was driven by an 


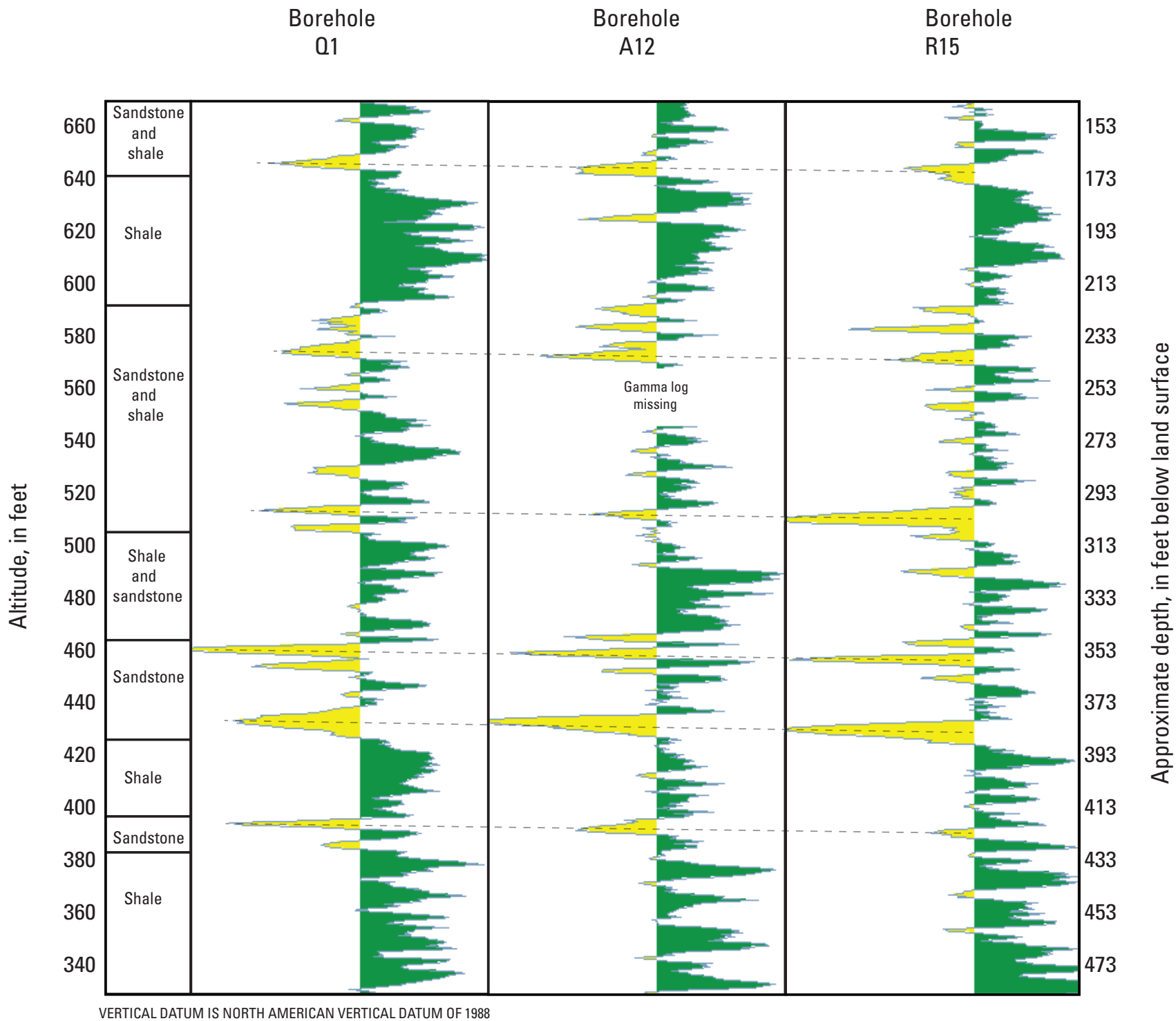

Figure 5. Gamma logs of boreholes $01, A 12$, and R15 and generalized lithology identified as sandstone-rich (yellow) and shalerich (green) based on relative gamma log response of the upper Devonian bedrock at the Owego-Apalachin Elementary School geothermal fields, Tioga County, New York. (Sandstone beds in the three boreholes connected by dotted lines, used to determine bedrock dip). 


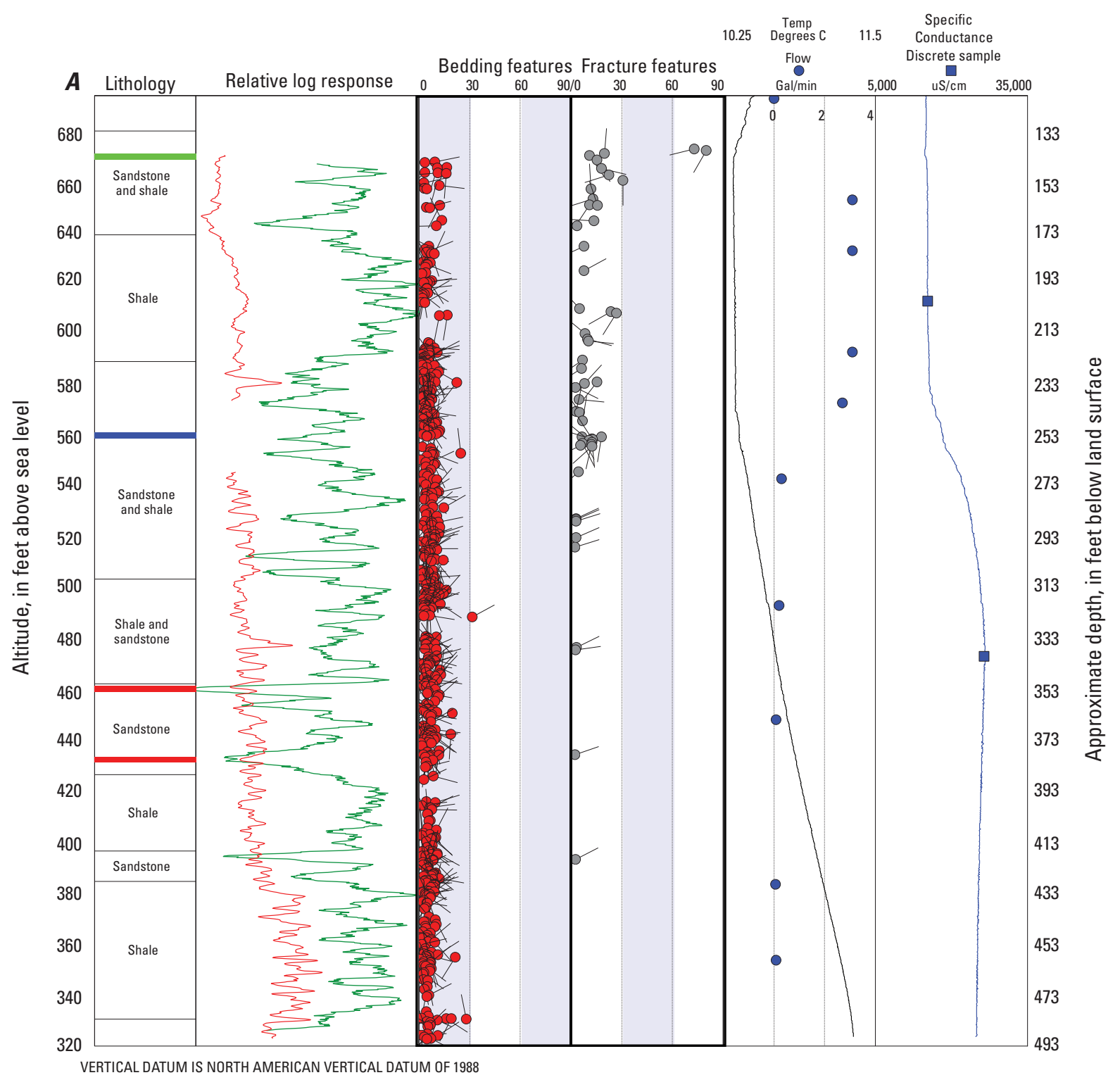

EXPLANATION

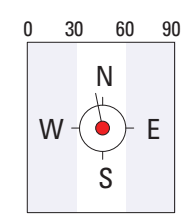

Planar feature delineated on optical televiewer (OTV) and acoustic televiewer (ATV) logs;

red "tadpole" indicates bedding and gray "tadpole" indicates fracture; "body" of tadpole indicates

dip angle in degrees, and "tail" indicates the dip (azimuth) in degrees relative to True Geographic North

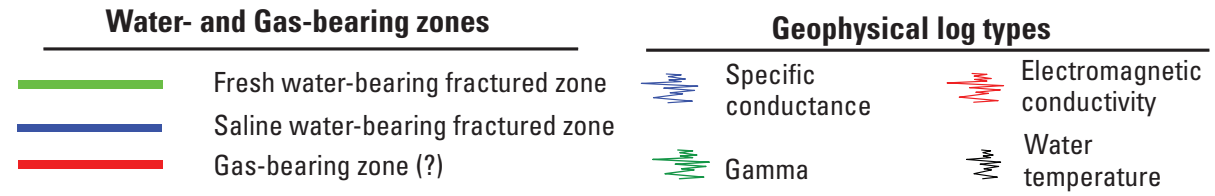

- Flow, positive values indicate upward flow

- Specific conductance discrete sample

Figure 6. Gamma, electromagnetic-conductivity, temperature, specific conductance, and flow logs and generalized lithology, bedding, fractures, and water- and gas-bearing zones in $A$, borehole 01 and $B$, borehole $A 9$ at the Owego-Apalachin Elementary School southwest geothermal field, Tioga County, New York. (Temp, temperature; C, Celsius; gal/min, gallons per minute; $\mu \mathrm{S} / \mathrm{cm}$, microsiemens per centimeter at 25 degrees Celsius; positive flow values indicate upward flow in this well) 


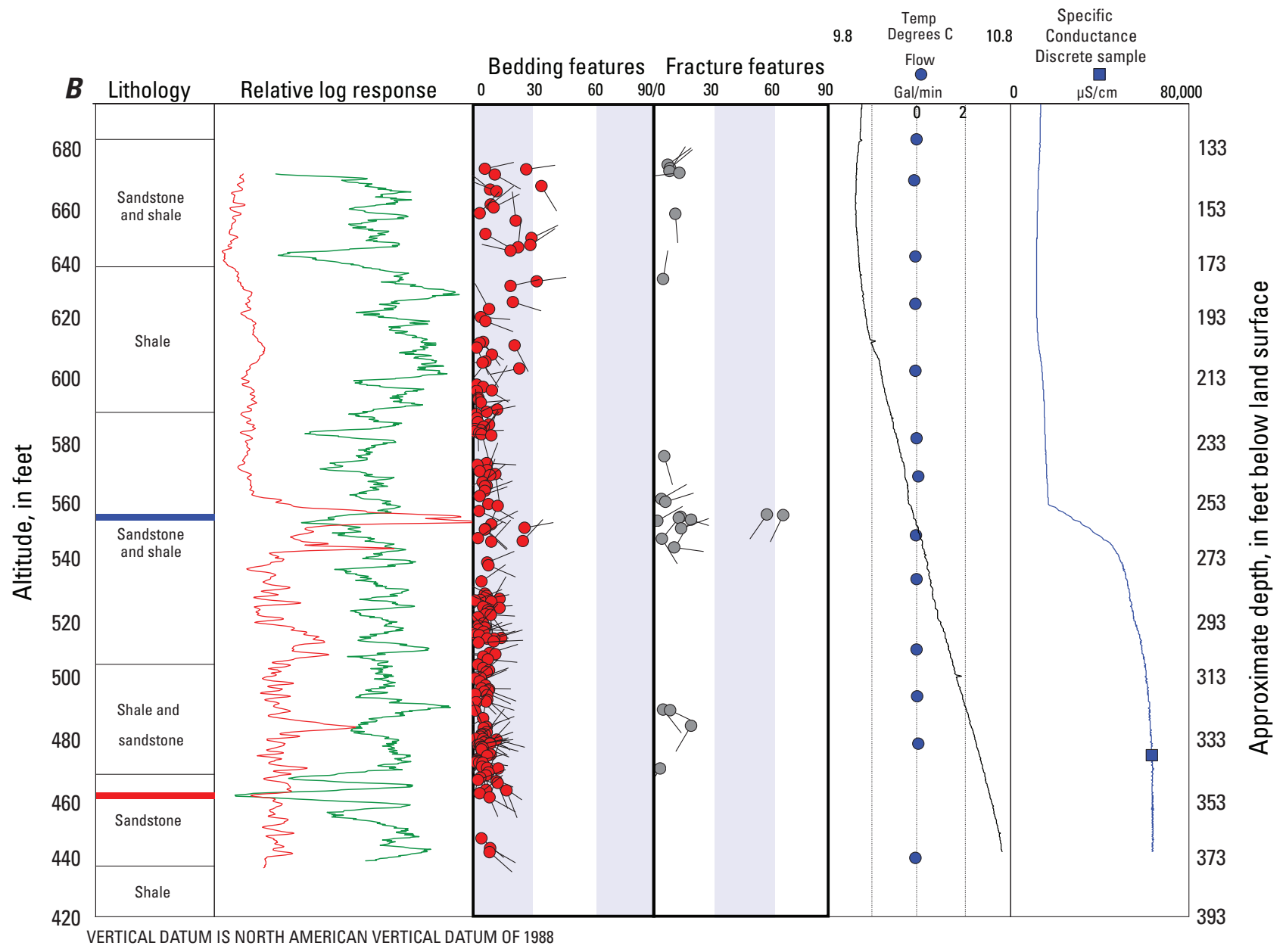

Figure 6. - Continued 


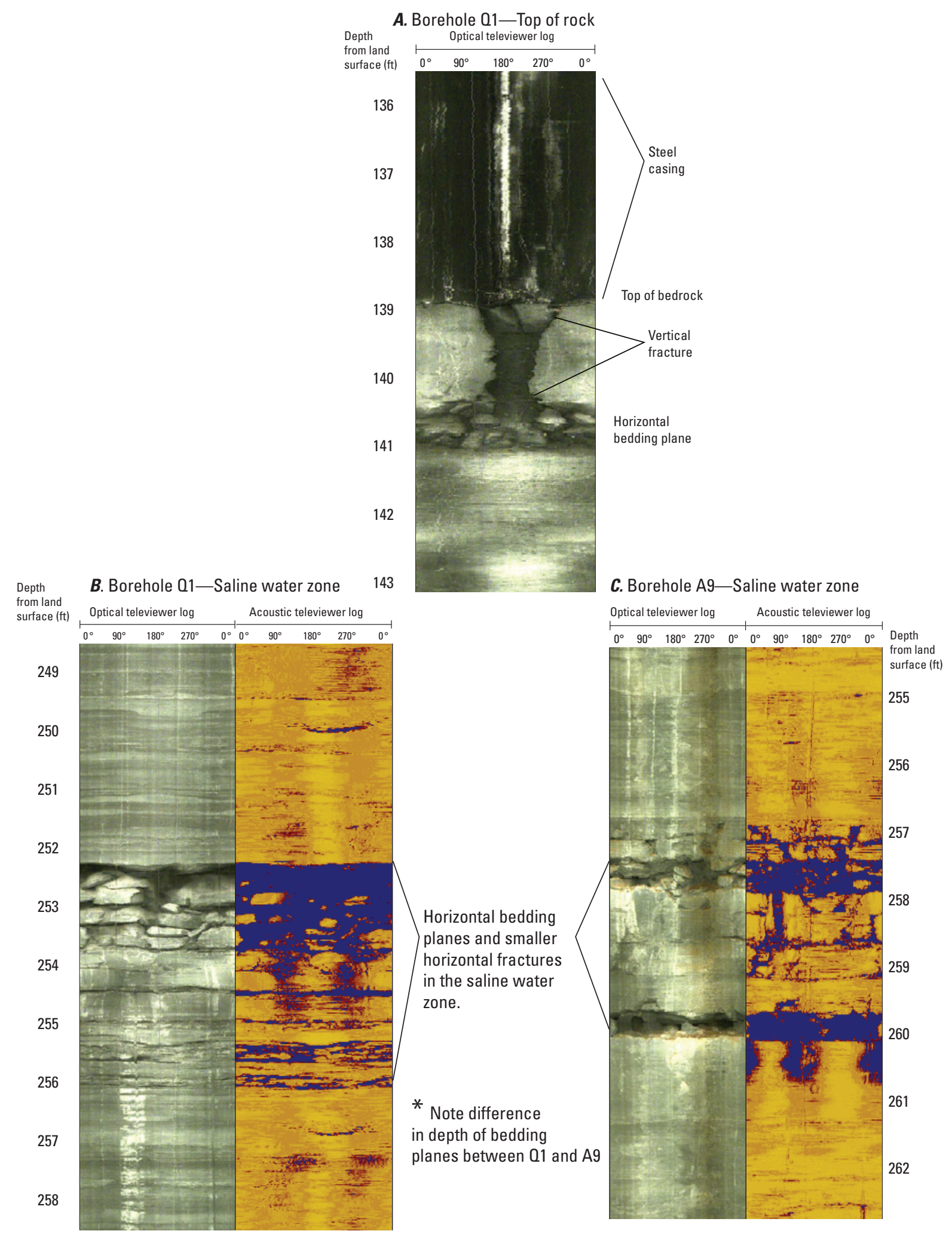

Figure 7. Optical- and acoustic-televiewer images of $A$, a freshwater-bearing fractured zone in borehole $01, B$, a saline water-bearing fractured zone in borehole 01 , and $C$, a saline water-bearing fractured zone in borehole $A 9$ at the Owego-Apalachin Elementary School southwest geothermal field, Tioga County, New York. (ft, foot; ${ }^{\circ}$, degree) 


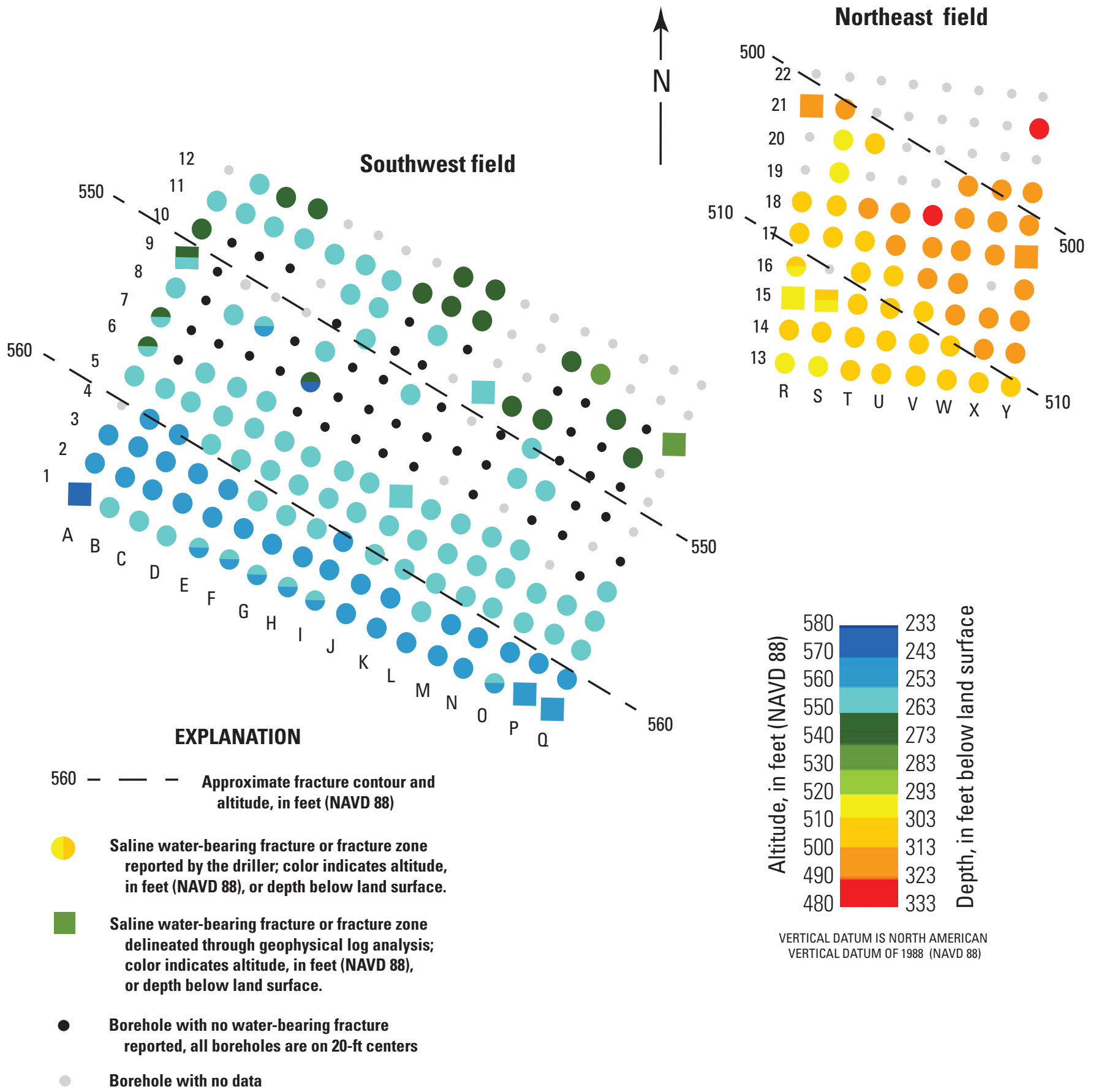

Figure 8. Altitude and depth from land surface of saline water-bearing fractured zones reported by the driller or delineated through geophysical-log analysis in boreholes at the Owego-Apalachin Elementary School geothermal fields, Tioga County, New York. 
upward hydraulic gradient between the saline-water zone and the freshwater zone. The specific conductance of the upward flow from the saline water-bearing zone, as indicated by the borehole-fluid $\log$ and a specific-depth water sample collected at $200 \mathrm{ft}$ bls $\left(613 \mathrm{ft}\right.$ asl), was about $15,300 \mu \mathrm{S} / \mathrm{cm}$ at $25^{\circ} \mathrm{C}$. In borehole Q1, the specific conductance below the major saline water-bearing zone, as indicated by the borehole-fluid log and a depth-specific sample at $340 \mathrm{ft}$ bls ( $473 \mathrm{ft}$ asl), was about $26,400 \mu \mathrm{S} / \mathrm{cm}$ at $25^{\circ} \mathrm{C}$. This borehole water presumably was produced from minor water-bearing fractures, the depth of which is not known other than deeper than the major fractured zone.

In borehole A9, no water-bearing zones were identified above the major saline water-bearing fractured zone at 553-556 ft asl (260-257 ft bls), and no borehole flow was detected when logging was conducted on April 14, 2014. However, the sharp change in specific conductance on the borehole-fluid log at the major fractured zone indicates that slow upward flow probably occurred below the flowmeterdetection limit from the fractured zone to shallower minor fractures. The specific-depth sample from $100 \mathrm{ft}$ in borehole A9 (table 1), which presumably was collected from the major saline-water fractured zone, had a specific conductance of about $16,700 \mu \mathrm{S} / \mathrm{cm}$ at $25^{\circ} \mathrm{C}$. In borehole $\mathrm{A} 1$, the specific conductance of the borehole-fluid log just above the major fractured zone, and presumably sourced from the fractured zone, is similar, $16,400 \mu \mathrm{S} / \mathrm{cm}$ at $25^{\circ} \mathrm{C}$.

The specific conductance of a specific-depth sample from borehole A9 at $340 \mathrm{ft}$ bls (473 ft asl) was $63,700 \mu \mathrm{S} / \mathrm{cm}$ at $25^{\circ} \mathrm{C}$. This water was likely produced by minor fractures deeper than the major fractured zone identified in this borehole and throughout the southwest field. The specific conductance of the water is nearly identical to that produced from the major water-bearing zone identified in the northeast field, which indicates that the deeper more saline zone may be present in the southwest field, although consisting of much less permeable and less obvious fractures.

During hydraulic-rotary drilling of borehole Q1 on April 4, 2014, water-level changes in borehole A9 indicated a hydraulic connection between the two boreholes across the southwest field (fig. 10). The boreholes are separated by a horizontal distance of about $360 \mathrm{ft}$. Water was circulated at about $40 \mathrm{gal} / \mathrm{min}$ to remove drill cuttings as the borehole was advanced. Little loss of drilling water was noticed, and there was no change in the water level in borehole A9 until the Q1 borehole penetrated saline water-bearing fractures at $560 \mathrm{ft}$ asl ( $253 \mathrm{ft} \mathrm{bls).} \mathrm{Following} \mathrm{penetration} \mathrm{of} \mathrm{these} \mathrm{fractures} \mathrm{at}$ about 12:30 daylight saving time (DST), significant loss of drilling water was observed, while the water level in A9 rose about 2 feet. The water level in borehole A9 declined when

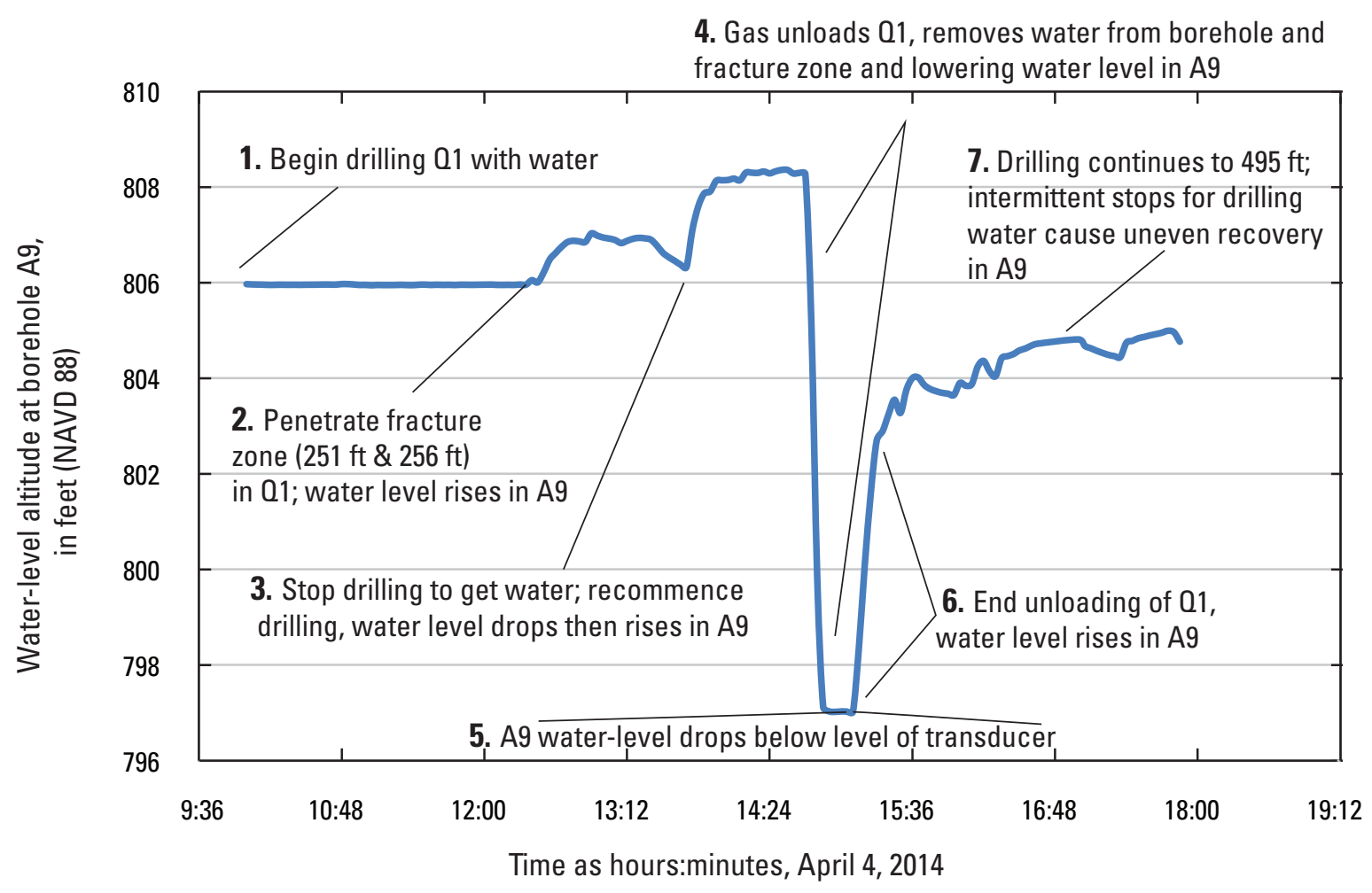

Figure 10. Water-level altitude in borehole A9 during hydraulic drilling and methane-gas unloading of borehole 01 at the Owego-Apalachin Elementary School geothermal fields, Tioga County, New York, April 4, 2014. 
drilling and water circulation was temporarily stopped from 13:20 to 13:40 DST to re-fill the water truck, then rose when drilling and water circulation resumed. Starting at 14:40 DST when the Q1 hole was at a depth of $415 \mathrm{ft}$ bls, methane gas dramatically unloaded the water column in the borehole causing more than $12 \mathrm{ft}$ of water-level decline in borehole A9. The methane gas blew more than $100 \mathrm{gal} / \mathrm{min}$ of water from the Q1 hole for about 15 minutes. The water level in A9 recovered more than $8 \mathrm{ft}$ within $40 \mathrm{~min}$ of the end of gas and water discharge. The water level continued to recover with minor fluctuations owing to periods of water circulation and water truck re-fillings as the hole was deepened to its final depth of $495 \mathrm{ft}$ bls.

During the morning of August 11, 2014, wastewater produced during drilling in the northeast field was periodically injected into borehole A9. The wastewater was injected at a rate of $143 \mathrm{gal} / \mathrm{min}$ for five 3.5-min-long periods with 12-30 min of recovery between the injection periods. The average water-level rise in borehole A9 in response to each injection was about $11 \mathrm{ft}$. The specific capacity of the borehole calculated from the injection rate and water-level rise is 13 gallons per minute per foot [(gal/min)/ft] (Theis, 1935). The aquifer transmissivity estimated from this short-term specific capacity test using the computer program of Bradbury and Rothschild (1985) and assuming a storage coefficient of $10^{-5}$ to $10^{-4}$ was $2,900-3,400 \mathrm{ft}^{2} / \mathrm{d}$.

Water-level changes in boreholes K9 and A1 during the repeated, short-term injections into borehole A9 indicate a hydraulic connection between those boreholes and borehole A9. The horizontal distances from boreholes K9 and A1 to borehole A9 are $200 \mathrm{ft}$ and $160 \mathrm{ft}$, respectively. Water levels in borehole $\mathrm{K} 9$ rapidly rose about $3.5 \mathrm{ft}$ (-3.5 ft displacement) in response to each injection in borehole A9 (fig. 11A). Water levels in borehole $\mathrm{K} 9$ rapidly dropped between injections each time recovering more than $3 \mathrm{ft}$. Although borehole A9 is $40 \mathrm{ft}$ closer to borehole A1 than to borehole K9, the water-level rise in borehole $\mathrm{A} 1$ in response to each injection was only about $1 \mathrm{ft}$ (fig. 11B). The recovery between injections was less complete in borehole $\mathrm{A} 1$ than in borehole $\mathrm{K}$; ; the starting level of the fifth injection was $1 \mathrm{ft}$ higher than that of the first injection.

Comparison of these water-level responses indicates that boreholes $\mathrm{A} 9$ and $\mathrm{K} 9$ are more strongly hydraulically connected than boreholes A9 and A1. The strong hydraulic connection between boreholes $\mathrm{A} 9$ and $\mathrm{K} 9$ probably occurred because the major fractured zone penetrated by these boreholes likely consists of the same, or is close to the same, bedding-related fractures (fig. 9C, in back of report). In contrast, the major fractured zone in borehole A1 is stratigraphically separated by about $20 \mathrm{ft}$ from the fractured zone in borehole A9 (fig. 9A, in back of report); therefore, the hydraulic connection is less direct. Although not directly comparable, the water-level changes in borehole A9 during drilling and methane-gas unloading of borehole Q1 (fig. 10) indicate that the hydraulic connection between those boreholes may be stronger than that between boreholes A9 and A1 as well. Borehole Q1 is more than $200 \mathrm{ft}$ farther away from borehole A9 than borehole A1 is from borehole A9. However, the major fractured zone in borehole Q1 is stratigraphically separated by about $8 \mathrm{ft}$ from the fractured zone in borehole A9 (figs. 9A and B, in back of report), which is less than one-half that for borehole A1. Hydraulic connection between subhorizontal, stacked bedding-plane fractures is limited by the number and transmissivity of higher-angle connecting fractures between them; therefore, locally, greater stratigraphic separation reduces connectivity more than the horizontal distance does.

The hydraulic properties of the major fractured zone were estimated through Theis type-curve analysis (Theis, 1935) of the water-level changes in boreholes $\mathrm{K} 9$ and $\mathrm{A} 1$ in response to injection into borehole A9. The transmissivity and storage coefficient of the fractured zone estimated from the waterlevel response in borehole $\mathrm{K} 9$ were about 1,450 feet squared per day $\left(\mathrm{ft}^{2} / \mathrm{d}\right)$ and $2 \times 10^{-5}$, respectively. The transmissivity and storage coefficient of the fractured zone estimated from the water-level response in borehole A1 were about $735 \mathrm{ft}^{2} / \mathrm{d}$ and $3 \times 10^{-4}$, respectively. The higher transmissivity and lower storage coefficient estimated from water-level fluctuations in borehole $\mathrm{K} 9$, compared to those from borehole $\mathrm{A} 1$, are consistent with the hydraulic connection between boreholes K9 and A9 being a direct hydraulic connection to a single or a few very closely spaced bedding-plane fractures rather than to an interconnected network of bedding-plane fractures and higher angle fractures.

Samples of saline water from boreholes A9 and Q1 in the southwest geothermal field are characterized by a chemical composition similar to that of deep formation brines collected from oil and gas wells in the Appalachian Basin. The depth-specific sample collected from borehole A9 at $340 \mathrm{ft}$ bls ( $473 \mathrm{ft}$ asl) had a total dissolved solids concentration of $40,200 \mathrm{mg} / \mathrm{L}$ and a dissolved chloride concentration of $24,200 \mathrm{mg} / \mathrm{L}$, whereas the dissolved sulfate concentration was less than $4 \mathrm{mg} / \mathrm{L}$ (appendix 3 ). The filtered barium concentration was $2,640,000 \mu \mathrm{g} / \mathrm{L}$, and the filtered strontium concentration was $237,000 \mu \mathrm{g} / \mathrm{L}$.

The saline waters collected from the borehole A9 at $340 \mathrm{ft}$ bls (473 ft asl) and Q1 at $200 \mathrm{ft}$ bls (613 ft asl) and $340 \mathrm{ft}$ bls (473 ft asl) are most likely derived from the mixing of formation brine with freshwater of the more active groundwater flow system (fig. 12). Groundwater, for which salinity is associated primarily with deicing salts, displays an increasing chloride to bromide ratio with increasing chloride concentrations until the chloride to bromide ratio becomes nearly constant at very elevated chloride concentrations $(>5,000 \mathrm{mg} / \mathrm{L})$. Groundwater, for which salinity is derived from the mixing of formation brine from oil and gas fields with freshwater, displays a nearly constant chloride to bromide ratio with increasing chloride concentrations. Most of the groundwater samples from domestic water wells in Sullivan County, north-central Pennsylvania, reported by Sloto (2013) plot on the "deicing line," whereas several plot on the "brine line." Selected groundwater samples from other sites in 


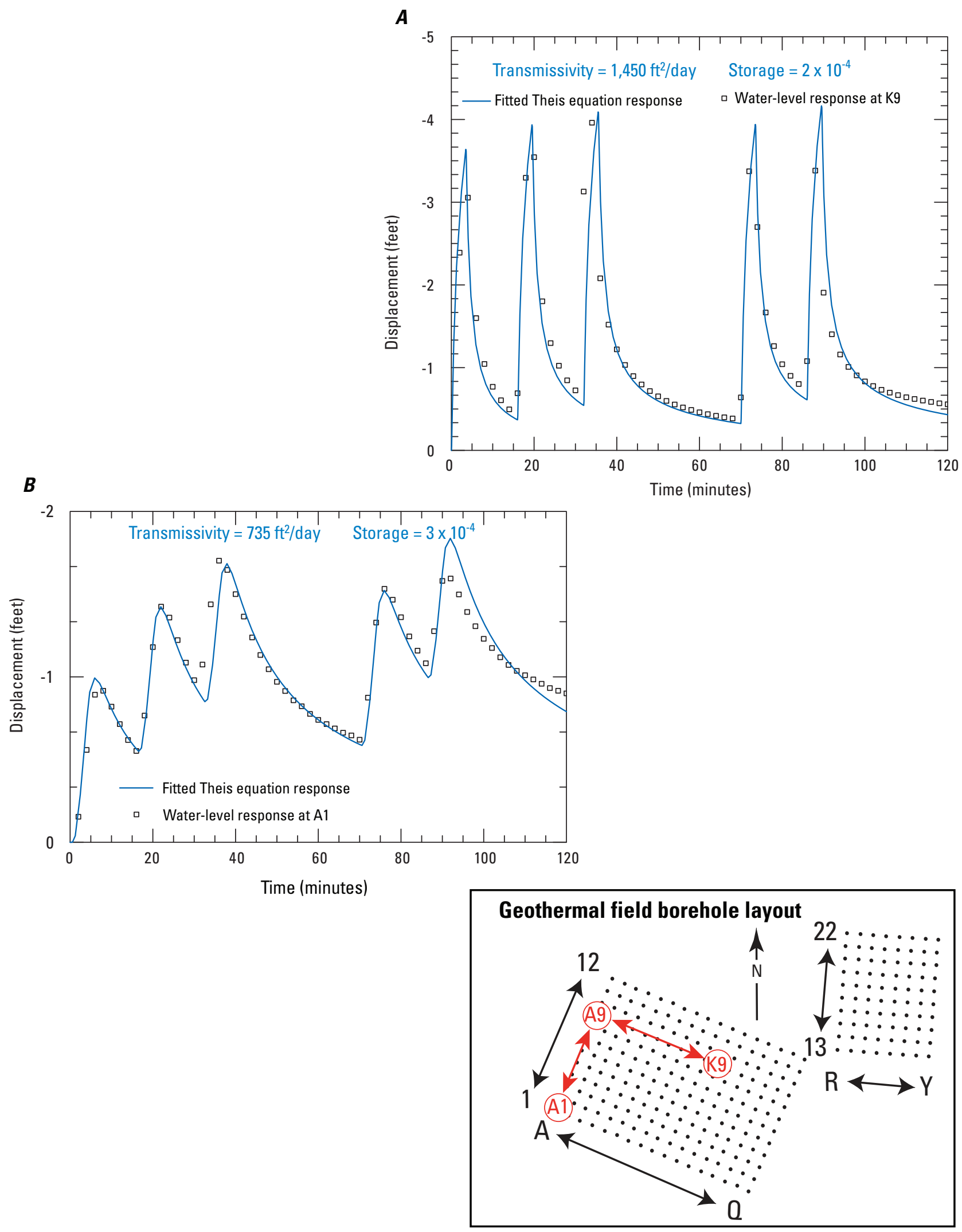

Figure 11. Water-level change in response to wastewater injections into borehole $A 9$ and Theis analysis match in $A$, borehole $\mathrm{K} 9$ and $B$, borehole $\mathrm{A} 1$ at the Owego-Apalachin Elementary School geothermal fields, Tioga County, New York, August 11, 2014. $\left(\mathrm{ft}^{2} / \mathrm{d}\right.$, feet squared per day; water-level rise indicated by negative displacement) 

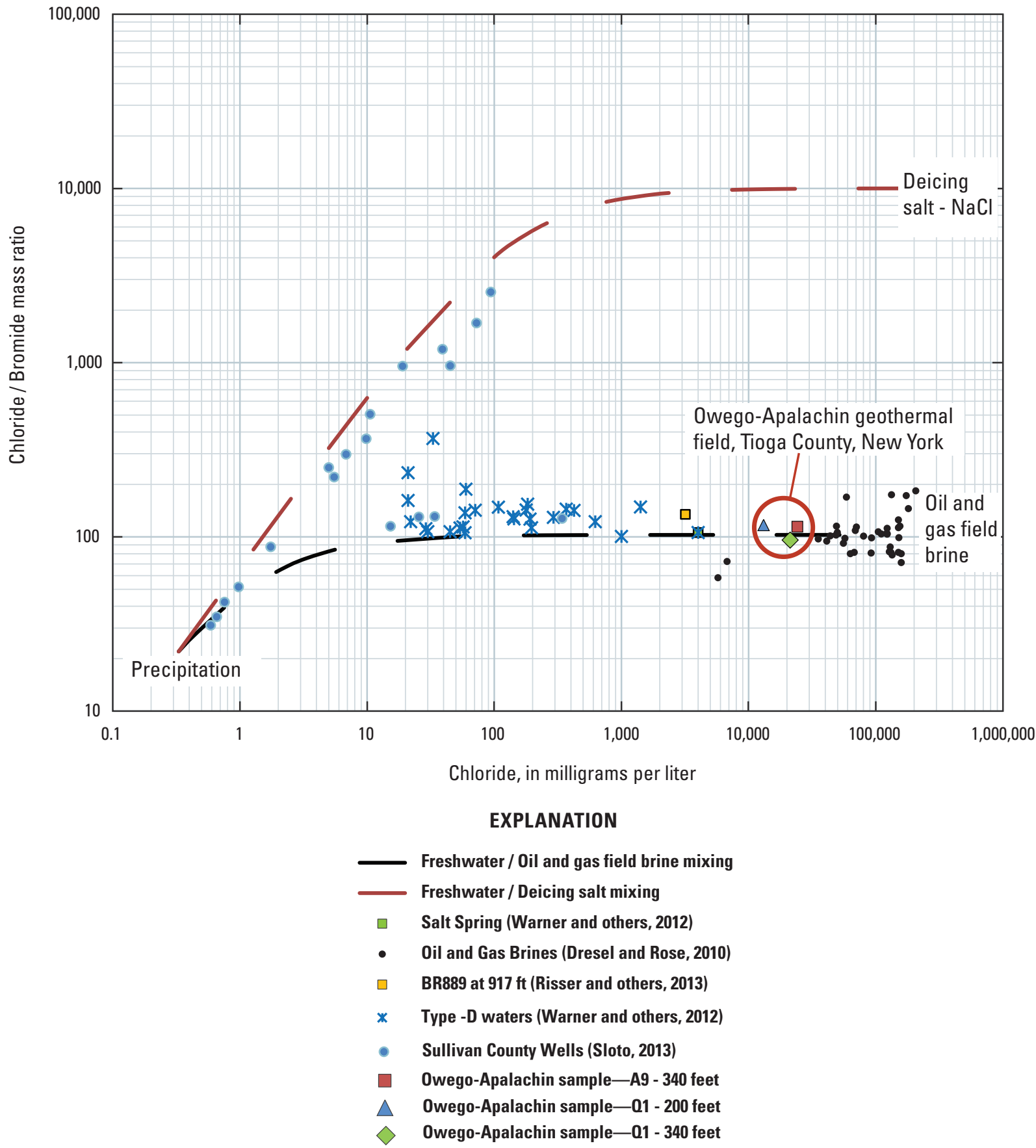

Figure 12. Chloride and chloride/bromide ratios for mixing of freshwater with deicing salt and with formation brine from oil and gas fields, selected groundwater samples from northeastern Pennsylvania, and saline-water samples from boreholes $\mathrm{A} 9$ and $\mathrm{Q1}$ at the Owego-Apalachin Elementary School geothermal fields, Tioga County, New York. (NaCl, sodium chloride) 
northeastern Pennsylvania, including those from domestic water wells classified as "Type D" by Warner and others (2012), a "salt spring"(Warner and others, 2012), and a deep upland test hole (BR889, Risser and others, 2013), plot on the "brine line." The saline waters collected from the boreholes A9 and Q1 plot closer to the oil and gas field brines than all the mixed brine-freshwater samples, indicating that the A9 and Q1 samples have a higher percentage of formation brine and are less diluted by freshwater than the other samples.

\section{Northeast Geothermal Field}

In the northeast geothermal field, the boreholes generally intersect bedding-plane fractures associated with a major saline water-bearing zone near the base of the thicker interbedded sandstone and shale interval. The major saline water-bearing zone in the northeast field is lower in altitude and lower in the stratigraphic section than that in the southwest field. In the southwestern corner of the northeast field, the major saline water-bearing fractured zone generally is at about $510 \mathrm{ft}$ asl (303 ft bls) (fig. 8). The fractured zone generally deepens to the northeast, ranging from 495 to $505 \mathrm{ft}$ asl (318 to $308 \mathrm{ft}$ bls). The lowest altitude of the fractured zone, $490 \mathrm{ft}$ asl (323 ft bls), was reported for boreholes V18 and $\mathrm{Y} 21$.

The hydrogeologic section from boreholes R15 to R21 (fig. 9E, in back of report) show that the deepest saline waterbearing fractures were penetrated by borehole R 21 at the northern end of the section. Borehole R21 penetrated a highly fractured zone that caused drilling difficulties and produced more than $100 \mathrm{gal} / \mathrm{min}$ of saline water during short-term development with compressed air. The borehole-fluid log, collected on August 11, 2014, less than 1 hour after drilling and air-blown development stopped, indicates the specific conductance of the water produced by the fractured zone was more than $60,000 \mu \mathrm{S} / \mathrm{cm}$ at $25^{\circ} \mathrm{C}$. In borehole R15, the specific conductance on the borehole-fluid log just above the major fractured zone, and presumably produced by the zone, was also more than $60,000 \mu \mathrm{S} / \mathrm{cm}$ at $25^{\circ} \mathrm{C}$.

The hydrogeologic section from boreholes R15 to Y17 (fig. 9F, in back of report) show that the deepest saline waterbearing fractures were penetrated by boreholes V16, V17, W16, W17, X16, X17, Y16, and Y17 along the eastern half of the section. In borehole Y17, the specific conductance of a specific-depth sample of the borehole water collected above the major saline water-bearing zone, which was presumably produced by the zone, was $66,000 \mu \mathrm{S} / \mathrm{cm}$ at $25^{\circ} \mathrm{C}$.

On August 11, 2014, following geophysical logging of the borehole and starting just before noon, wastewater produced during drilling of the northeast field $\mathrm{R}$ boreholes was injected into borehole Y17. The wastewater was continuously injected for about an hour at a rate of $70 \mathrm{gal} / \mathrm{min}$. The stabilized water-level rise in the borehole in response to this injection was $15.8 \mathrm{ft}$. The specific capacity of the borehole calculated from the injection rate and water-level rise was $4.4(\mathrm{gal} / \mathrm{min}) / \mathrm{ft}$. The transmissivity estimated from this short-term specific capacity test using the computer program of Bradbury and Rothschild (1985) and assuming a storage coefficient of $10^{-5}$ to $10^{-4}$ was 1,050 to $1,230 \mathrm{ft}^{2} / \mathrm{d}$.

Water-level changes in borehole Y17 during drilling in the $\mathrm{R}$ boreholes by the hydraulic-rotary and air-percussion rigs on August 11,2014, indicate that the major fractured zone is hydraulically connected across the northeast field. However, specific hydraulic connections and properties were not established because of the complex effect of the (1) concurrent hydraulic-rotary and air-percussion drilling and (2) sporadic wastewater injection into borehole Y17 after the initial hourlong steady-rate injection.

No specific-depth samples of borehole water were collected in the northeast geothermal field for laboratory chemical analyses. However, the range of the specific conductance of water from the major water-bearing fractured zone in the northeast field $\left(60,000-66,000 \mu \mathrm{S} / \mathrm{cm}\right.$ at $\left.25^{\circ} \mathrm{C}\right)$, as measured in boreholes R15, R21, and Y17, closely spans the specific conductance of the specific-depth sample at $340 \mathrm{ft}$ bls in borehole A9 $\left(64,900 \mu \mathrm{S} / \mathrm{cm}\right.$ at $\left.25^{\circ} \mathrm{C}\right)$ in the southeast geothermal field. This indicates that water from the major fractured zone in the northeast field has brine-related chemical constituents and concentrations that are very similar to that of the deep specific-depth sample from borehole A9.

\section{Gas-Bearing Zones}

The OAES geothermal fields intersect methane gasbearing zones below the major saline water-bearing zones. Of the 284 boreholes, 113 (about 40 percent) reportedly discharged methane gas to land surface when drilled. About one-third of the boreholes in the southwest field reportedly blew gas, whereas about one-half of those in the northeast field reportedly did the same (fig. 13). The vast majority of the boreholes blew gas for less than 30 minutes following drilling, but a few blew for days.

Methane gas violently unloaded the water columns in boreholes A9, A12, and Q1, the first boreholes drilled in the southwest field. Methane gas and water began discharging from boreholes A9 and Q1 at depths of 435 and $400 \mathrm{ft}$ asl (378 and $413 \mathrm{ft}$ bls), respectively. Methane gas and water began discharging from borehole A12 at its completed depth of $495 \mathrm{ft}$ bls as the drilling rods were being pulled from the hole (see appendix 4 for video of borehole A12 unloading). Methane gas reportedly began discharging from boreholes R14, R17, R18, R19, and R20, which were among the first drilled in the northwest field, at depths of $375-395 \mathrm{ft}$ asl (438-418 ft bls). Because the methane gas has to overcome the hydraulic head prior to discharging at the land surface, the source beds for the gas in all these boreholes would be at somewhat shallower depths than the depths at which gas was first observed to discharge.

The probable primary sources of the methane gas in the southwest geothermal field are sandstones beds at 435 and 


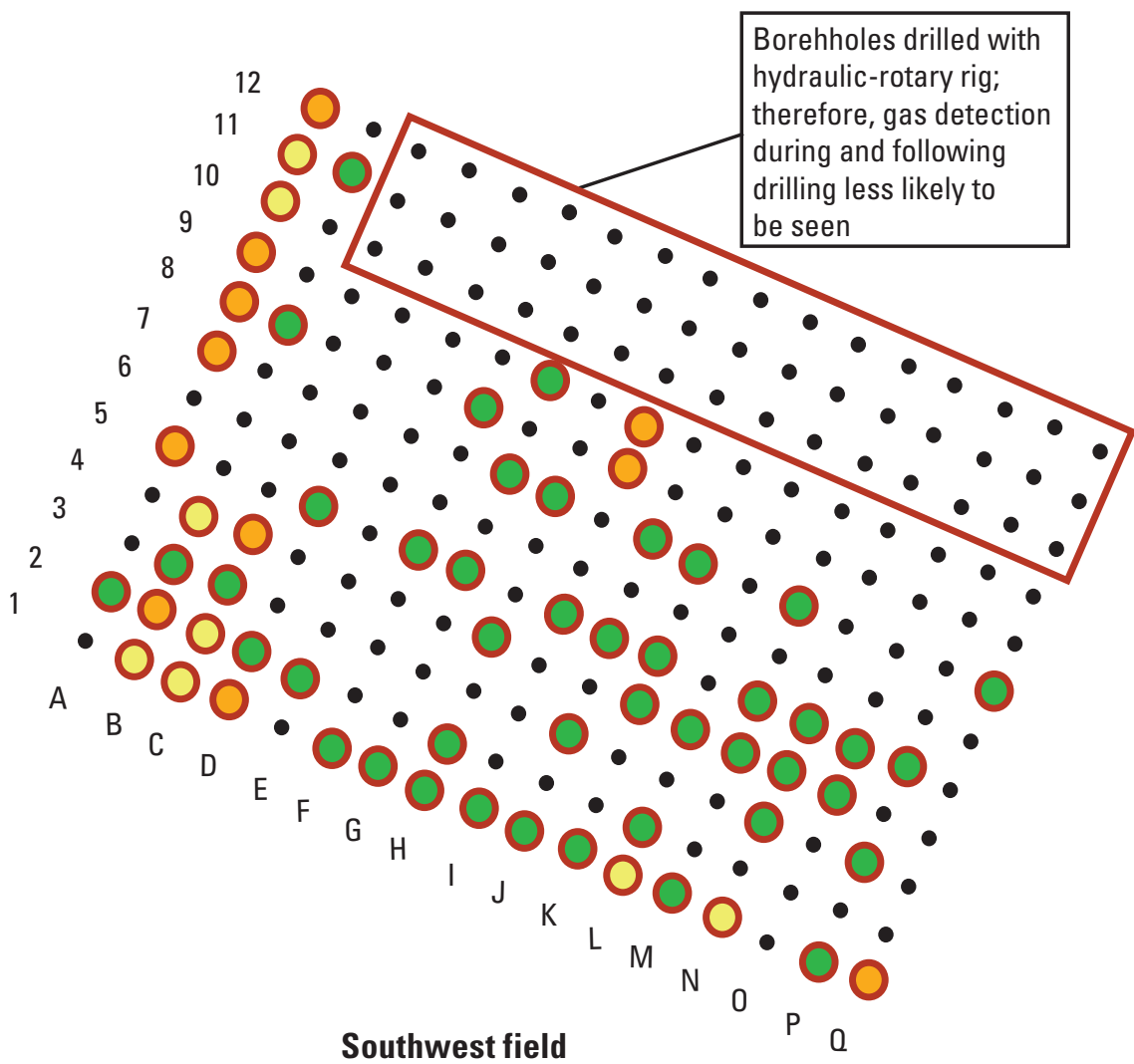

Southwest field
$\stackrel{\uparrow}{N}$

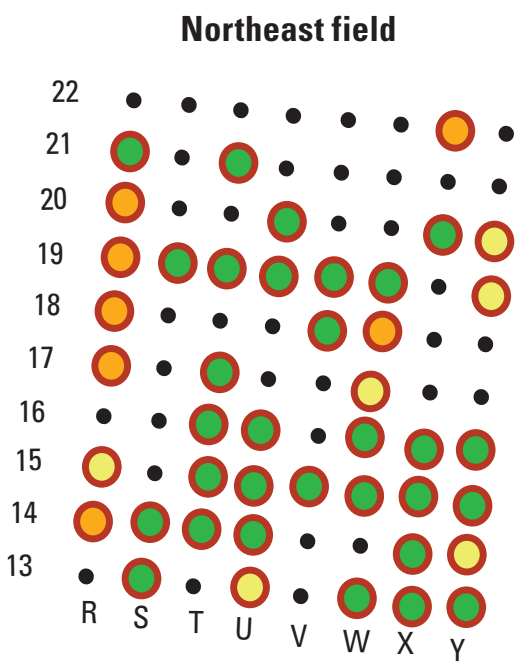

EXPLANATION

Borehole with gas discharge during drilling

Borehole with gas discharge following drilling, greater than $\mathbf{3 0}$ minutes of gas discharge

Borehole with gas discharge following drilling, less than 30 minutes of gas discharge

- Borehole with no reported gas discharge

Figure 13. Occurrence of methane-gas discharge at land surface during and following drilling of boreholes, as reported by the driller/consultant at the Owego-Apalachin Elementary School geothermal fields, Tioga County, New York.

$465 \mathrm{ft}$ asl (378 and $348 \mathrm{ft}$ bls) (figs. $6 \mathrm{~A}$ and B). Because a porous media filled with gas is more electrically resistive than one filled with saline water, the sandstone beds that are probably methane-gas bearing are characterized by lower electromagnetic conductivity than those sandstone beds that are saline water bearing. Methane gas-bearing sandstones of Late Devonian age have been developed on a limited commercial basis in northeastern Pennsylvania. According to Carter and Harper (2002), primary porosity in the sandstones is minimal owing to compaction, cementation, and mineral replacement, and most of the porosity is secondary through diagenetic dissolution of cements, unstable grains, and minerals, and where fractures are present.

The specific-depth sample collected from borehole A9 at $340 \mathrm{ft}$ (473 ft bls) had a methane concentration of $83 \mathrm{mg} / \mathrm{L}$, a methane carbon-13 delta $(\delta 13 \mathrm{C})$ of -45.88 per mil (\%o), and a delta deuterium $(\delta 2 \mathrm{H})$ of $-244.6 \%$. The sample probably included both dissolved and free-phase methane present at that depth and time in the borehole-water column. The free-phase methane was bubbling up from the gas-bearing zone, and the dissolved methane was transported along with the very small amount of inflow from minor fractures associated with the deeper saline water-bearing zone. The isotopic composition of the methane sample indicates an early thermogenic origin; the composition is similar to that of upper Devonian bedrock groundwater samples from domestic water wells in valleys in south-central New York (Heisig and Scott, 2013) and domestic water wells in valleys (Sloto, 2013), a salt spring (Molofsky and others, 2011), and a deep upland test hole (Risser and others, 2013) in northeastern Pennsylvania (fig. 14). 


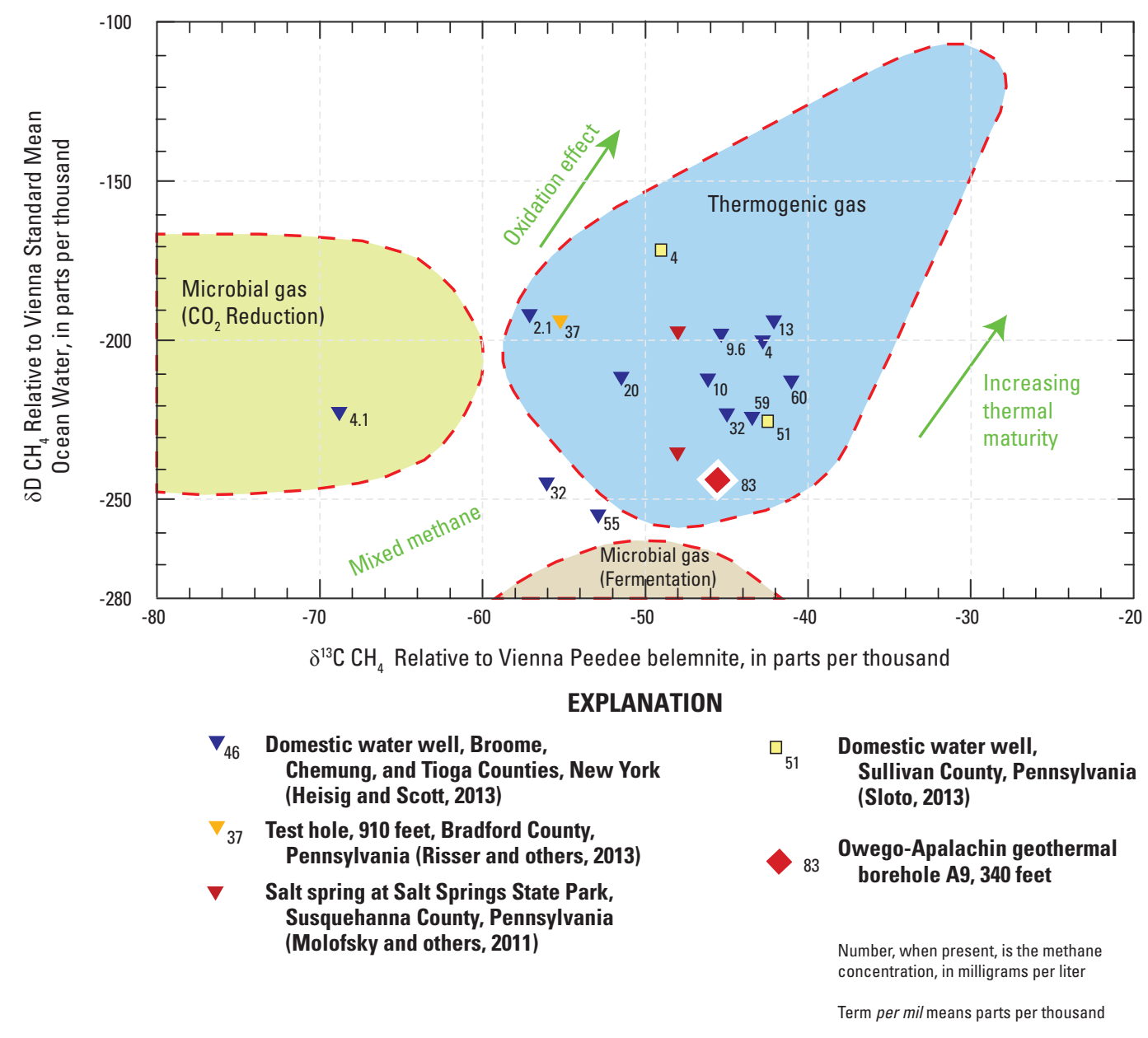

Figure 14. Stable-isotopic composition of carbon and hydrogen in methane in upper Devonian bedrock groundwater samples from water wells in south-central New York; water wells, a salt spring, and a test hole in northeastern Pennsylvania; and borehole A9 at the Owego-Apalachin Elementary School geothermal fields, Tioga County, New York. $\left(\delta \mathrm{D} \mathrm{CH}_{4}\right.$ stable-isotopic compostion of hydrogen in methane; $\delta{ }^{13} \mathrm{CCH}_{4^{\prime}}$, table-isotopic compostion of carbon in methane; $\mathrm{CO}_{2^{\prime}}$ carbon dioxide). Methane isotope ratio source fields from Revesz and others (2012).

\section{Summary and Conclusions}

Construction of the new Owego-Apalachin Elementary School (OAES), following extensive flooding damage, included drilling and installation of 284 closed-loop geothermal boreholes in two fields within the Owego Creek valley in Tioga County, New York. During drilling of the first borehole into the upper Devonian bedrock, a major fractured zone bearing saline water was penetrated at 260 feet below land surface (ft bls). When drilling continued to $380 \mathrm{ft}$ bls, methane gas unloaded the borehole water column, ignited, and burned the drilling rig.

Given the presence of saline water and methane gas, hydrogeologic information was needed to develop a plan for the drilling and completion of the OAES geothermal boreholes with specific protocols to protect human health and property, as well as the local groundwater resources. Collection of hydrogeologic data, which included drilling and geophysical logs, water-level monitoring data, and the water chemistry of depth-specific samples, became an integral part of the geothermal-field construction, prior to and during the fullscale borehole drilling program.

The 495-ft deep geothermal boreholes are cased through $130 \mathrm{ft}$ of valley fill and completed in upper Devonian bedrock. The bedrock strata consist of shale and sandstone that dip very gently to the north-northeast. The southwest geothermal field, which consists of 204 boreholes, penetrates a major saline water-bearing zone associated with bedding-plane fractures 
near the middle of an interbedded sandstone and shale interval at depths of 238 to $263 \mathrm{ft}$ bls. The northeast geothermal field, which consists of 80 boreholes, penetrates a major saline water-bearing zone associated with bedding-plane fractures near the base of the interbedded sandstone and shale interval at depths of 303 to 323 bls.

Transmissivity of the major saline water-bearing zones estimated from specific-capacity data and Theis analysis of water-level data collected during drilling wastewater injection ranged from 735 to 3,400 feet squared per day. The saline water-bearing fractured zone in the southwest field is hydraulically connected over a horizontal distance of more than 350 feet. The hydraulic connection between subhorizontal, stacked bedding-plane fractures is limited by the number and transmissivity of the interspersed higher angle fractures, which leads to locally greater stratigraphic separation that reduces connectivity more than does the horizontal distance.

The specific conductance of the saline water from the major fractured zone in the southwest field was about 16,000 microsiemens per centimenter at 25 degrees Celsius $\left(\mu \mathrm{S} / \mathrm{cm}\right.$ at $\left.25^{\circ} \mathrm{C}\right)$, and that from the major fractured zone in the northeast field was about $65,000 \mu \mathrm{S} / \mathrm{cm}$ at $25^{\circ} \mathrm{C}$. The saline waters were characterized by a chemical composition similar to that of the deep formation brines sampled from oil and gas wells in the Appalachian Basin. About 40 percent of the geothermal wells discharged methane gas to land surface during and (or) following drilling. Sandstone beds at a depth of 348 to $378 \mathrm{ft}$ bls are the likely source of the methane gas, which is determined to be early thermogenic in origin.

The hydrogeologic characterization proved beneficial in the design and execution of the geothermal-well drilling program. The hydrogeologic insights gained in this study can be applied to future geothermal and hydrocarbon development in similar fractured-bedrock settings.

\section{References Cited}

Bradbury, K.R., and Rothschild, E.R., 1985, A computerized technique for estimating the hydraulic conductivity of aquifers from specific-capacity data: Ground Water, v. 23, no. 2, p. 240-246.

Carter, K.M., and Harper, J.A., 2002, Oil and gas prospects in northeastern Pennyslvania, in Inners, J.D., and Fleeger, G.M., eds., From Tunkhannock to Starrucca: Bluestone, glacial lakes, and great ridges in the Endless Mountains of northeastern Pennsylvania: Guidebook for the 67th Annual Field Conference of Pennsylvania Geologists, Tunkhannock, Pa., p. 15-31.

Dresel, P.E., and Rose, A.W., 2010, Chemistry and origin of oil and gas well brines in western Pennsylvania: Pennsylvania Geological Survey, 4th ser., Open-File Report OFOG 10-01.0, 48 p., Portable Document Format (PDF).
Enviroscan Incorporated, 2014, Final report-Owego School geothermal well field gas and brine management oversight, Owego Elementary School, Owego, N.Y.: Enviroscan Reference Number 051421, Appendix 'A'-Owego School Geothermal Well Drilling Specifications, rev. 3, 2 p.

Heisig, P.M., and Scott, Tia-Marie, 2013, Occurrence of methane in groundwater of south-central New York State, 2012-Systematic evaluation of a glaciated region by hydrogeologic setting: U.S. Geological Survey Scientific Investigations Report 2013-5190, 32 p., http://dx.doi. org/10.3133/sir20135190.

Keys, W.S., 1990, Borehole geophysics applied to groundwater investigations: U.S. Geological Survey Techniques of Water-Resources Investigations, book 2, chap. E2, p. 150.

Molofsky, L., Connor, J., Wylie, A., and Wagner, T., 2011, Methane in Pennsylvania water wells unrelated to Marcellus shale fracturing: Oil and Gas Journal, v. 109, no. 49, 12 p., accessed January 23, 2012, at http://www.ogj.com/1/ vol-109/issue-49/exploration-development/methane-inpennsylvania-water-full.html.

Randall, A.D., 1972, Records of wells and test borings in the Susquehanna River basin: New York Department of Environmental Conservation Bulletin 69, 92 p.

Révész, K.M., Breen, K.J., Baldassare, A.J., and Burruss, R.C., 2012, Carbon and hydrogen isotopic evidence for the origin of combustible gases in water-supply wells in north-central Pennsylvania: Applied Geochemistry, v. 27, p. 361-375.

Reynolds, R.J., and Garry, J.D., 1990, Hydrogeology of the valley-fill aquifer at Owego, Tioga County, New York: U.S. Geological Survey Water-Resources Investigations Report 89-4000, 8 sheets, scale 1:24,000.

Rider, M., and Kennedy, M., 2011, The geological interpretation of borehole logs: Rider-French Consulting Limited (3d ed.): Glasgow, Bell and Bain, 432 p.

Risser, D.W., Williams, J.H., Hand, K.L., Behr, Rose-Anna, and Markowski, A.K., 2013, Geohydrologic and waterquality characterization of a fractured-bedrock test hole in an area of Marcellus Shale gas development, Bradford County, Pennsylvania: Pennsylvania Geological Survey, 4th ser., Open-File Miscellaneous Report OFMI 13-01.0, 48 p.

Sloto, R.A., 2013, Baseline groundwater quality from 20 domestic wells in Sullivan County, Pennsylvania, 2012: U.S. Geological Survey Scientific Investigations Report 2013-5085, 27 p., http://pubs.usgs.gov/sir/2013/5085/.

Theis, C.V., 1935, The relation between the lowering of the piezometric surface and the rate and duration of discharge of a well using ground-water storage: American Geophysical Union Transactions, v. 16, p. 519-524. 
U.S. Geological Survey, variously dated, National field manual for the collection of water-quality data: U.S. Geological Survey Techniques of Water-Resources Investigations, book 9, chaps. A1-A9, http://pubs.water.usgs.gov/twri9A.

Warner, N.R., Jackson, R.B., Darrah, T.H., Osborn, S.G., Down, Adrian, and Zhao, Kaiguang, 2012, Geochemical evidence for possible natural migration of Marcellus Formation brine to shallow aquifers in Pennsylvania: Proceedings of the National Academy of Sciences, v. 109, no. 30, p. 11961-11966.

Wedel, A.A., 1932, Geologic structure of the Devonian strata of south-central New York: New York State Museum Bulletin No. 204, The University of the State of New York, 94 p. 


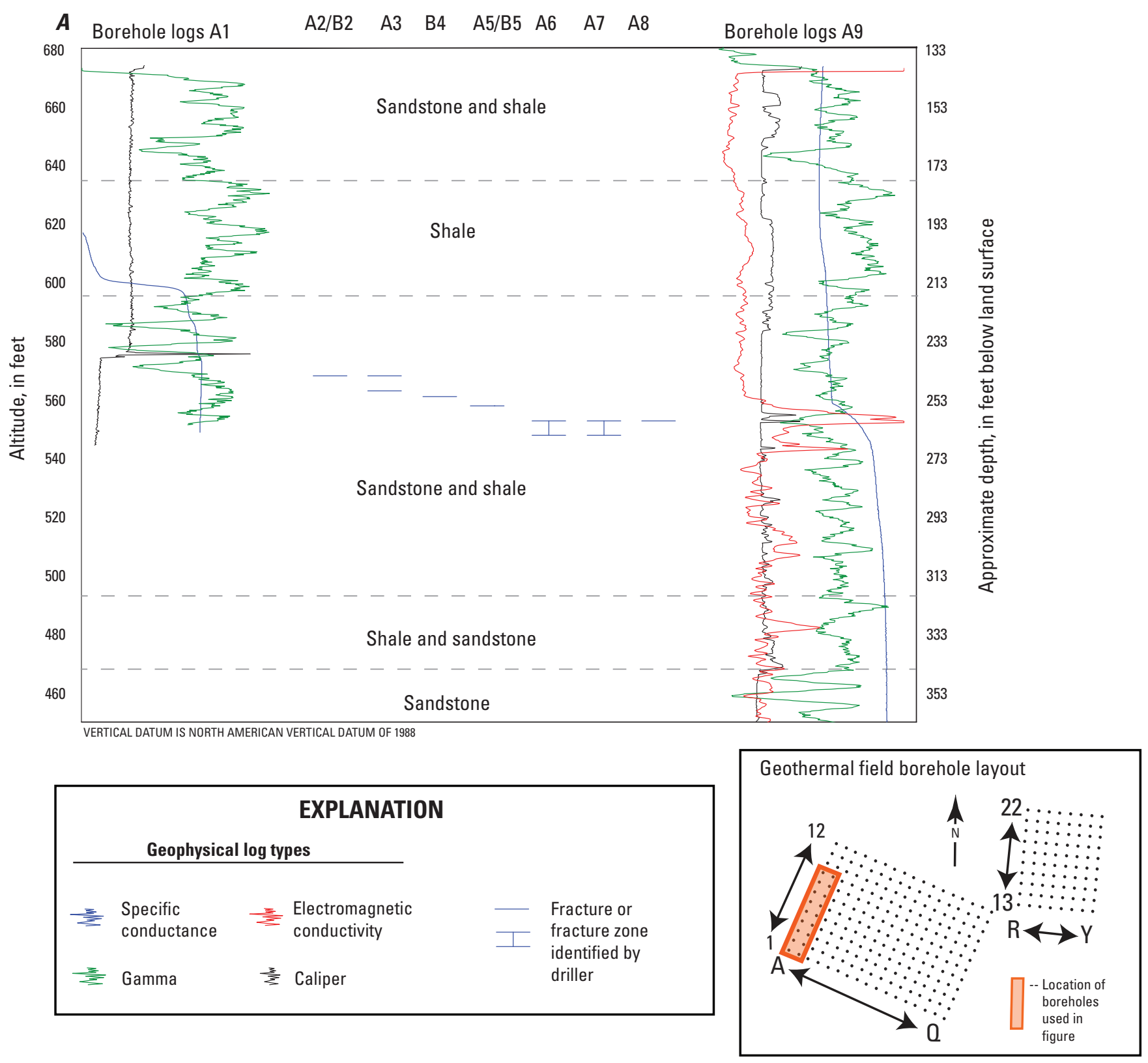

Figure 9. Gamma, caliper, electromagnetic-conductivity, and specific-conductance logs, showing relative log response, and saline water-bearing fractured zones reported by the driller in selected boreholes at the Owego-Apalachin Elementary School geothermal fields, Tioga County, New York: $A$, borehole A1 to borehole A9; $B$, borehole 01 to borehole 010; $C$, borehole $A 9$ to borehole K9; $D$, borehole $\mathrm{K} 9$ to borehole $010 ; E$, borehole R15 to borehole R21; and $F$, borehole R15 to borehole Y17. 


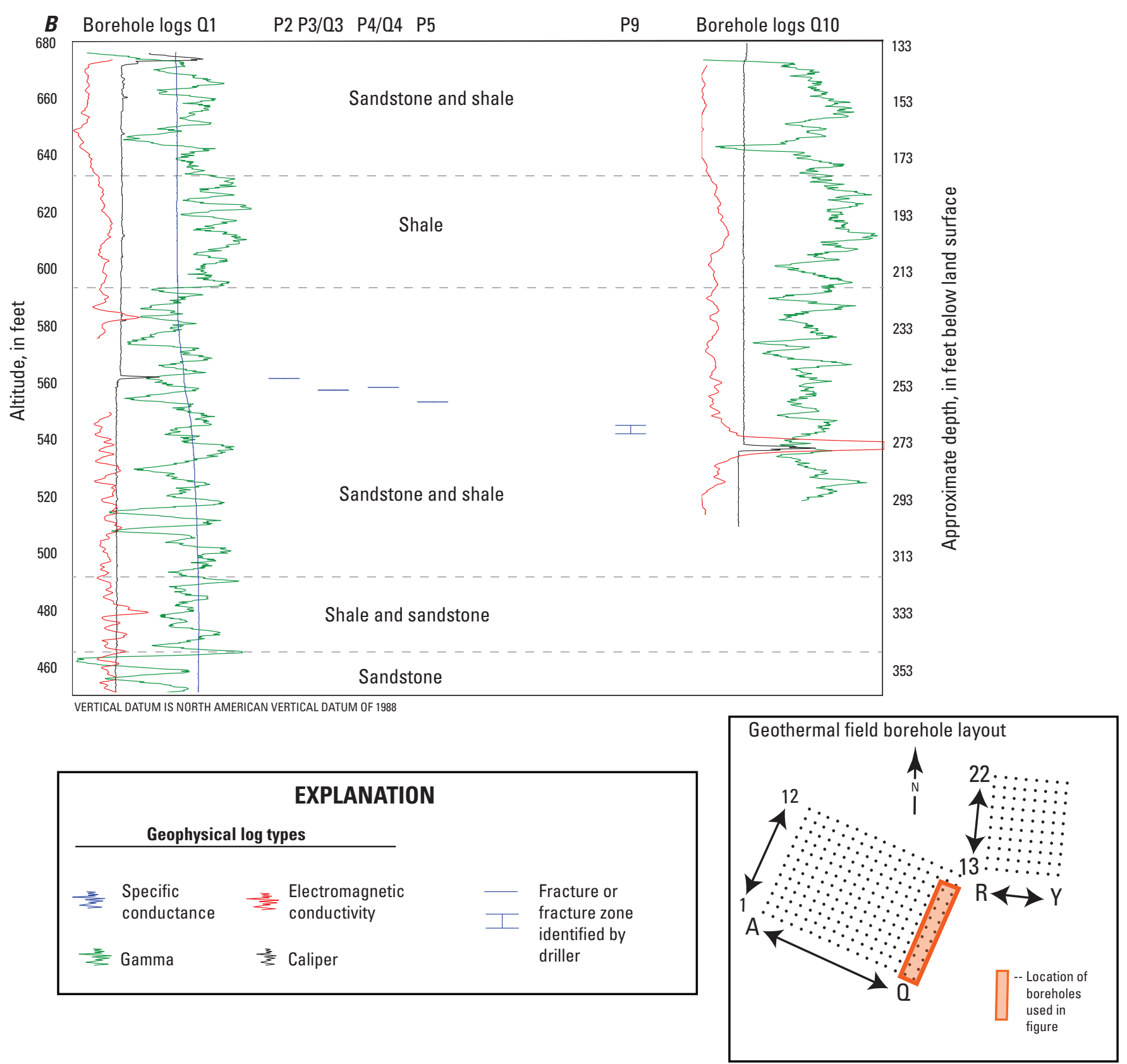

Figure 9. Gamma, caliper, electromagnetic-conductivity, and specific-conductance logs, showing relative log response, and saline water-bearing fractured zones reported by the driller in selected boreholes at the Owego-Apalachin Elementary School geothermal fields, Tioga County, New York: $A$, borehole $\mathrm{A} 1$ to borehole $\mathrm{A} 9 ; \mathrm{B}$, borehole 01 to borehole $010 ; C$, borehole $\mathrm{A} 9$ to borehole $\mathrm{K} 9$; $D$, borehole $\mathrm{K} 9$ to borehole $\mathrm{Q10}$; $E$, borehole R15 to borehole R21; and $F$, borehole R15 to borehole Y17.—Continued 


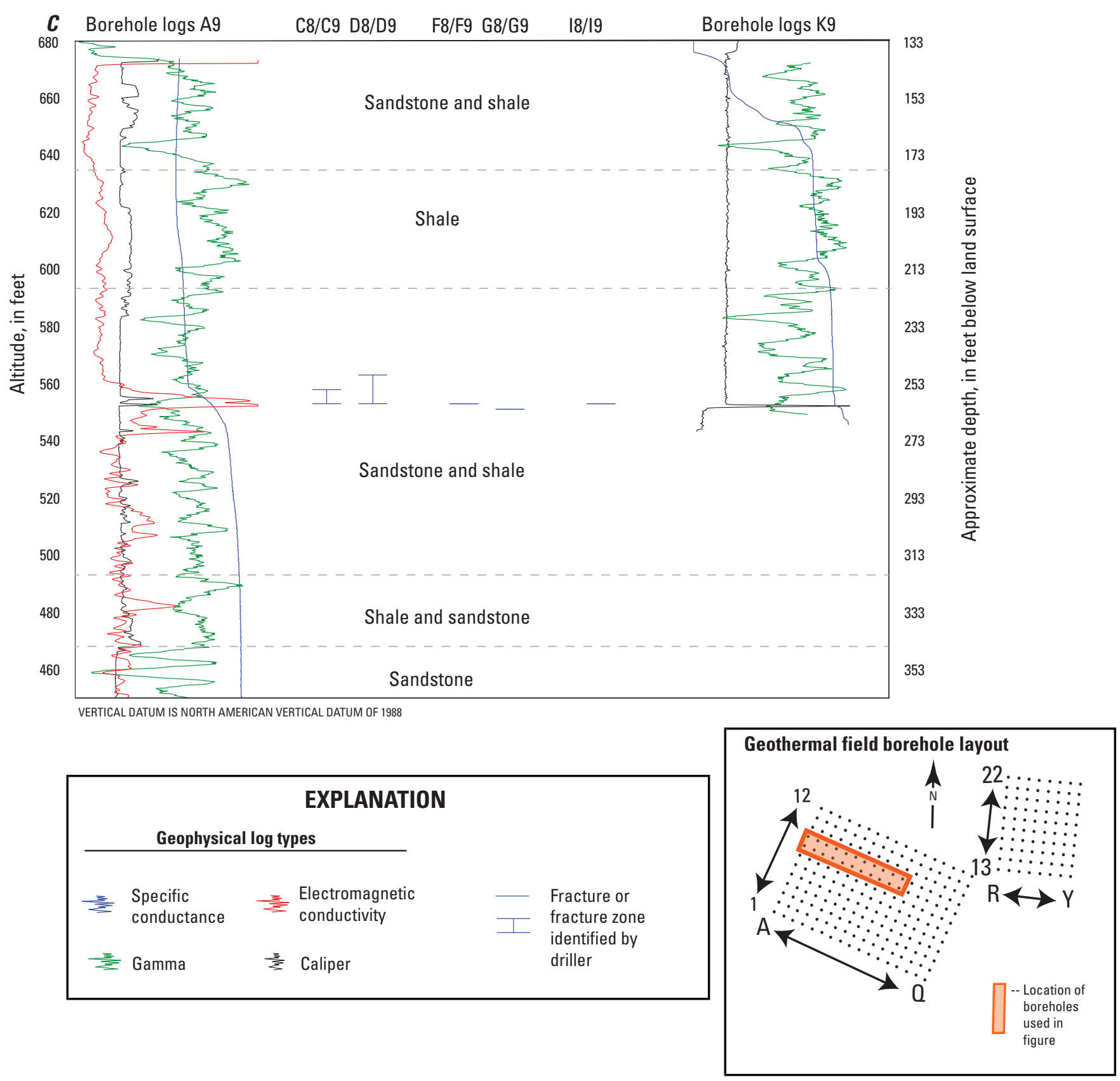

Figure 9. Gamma, caliper, electromagnetic-conductivity, and specific-conductance logs, showing relative log response, and saline water-bearing fractured zones reported by the driller in selected boreholes at the Owego-Apalachin Elementary School geothermal fields, Tioga County, New York: $A$, borehole A1 to borehole A9; $B$, borehole 01 to borehole $010 ; C$, borehole A9 to borehole K9; $D$, borehole $\mathrm{K} 9$ to borehole 010 ; $E$, borehole R15 to borehole R21; and $F$, borehole R15 to borehole Y17. - Continued 


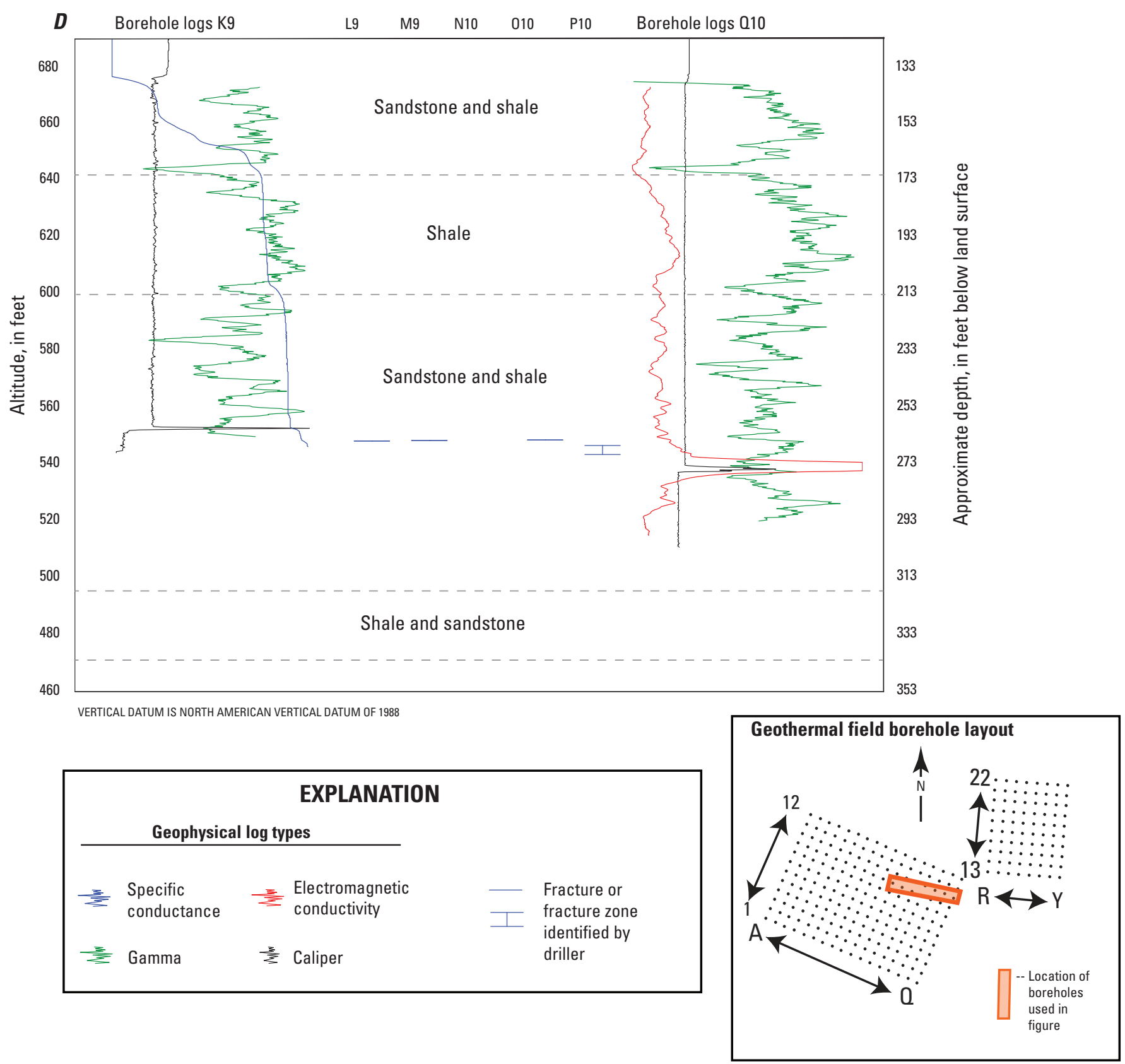

Figure 9. Gamma, caliper, electromagnetic-conductivity, and specific-conductance logs, showing relative log response, and saline water-bearing fractured zones reported by the driller in selected boreholes at the Owego-Apalachin Elementary School geothermal fields, Tioga County, New York: $A$, borehole $A 1$ to borehole A9; $B$, borehole 01 to borehole 010; $C$, borehole A9 to borehole K9; $D$, borehole $\mathrm{K} 9$ to borehole 010 ; $E$, borehole R15 to borehole R21; and $F$, borehole R15 to borehole Y17.-Continued 


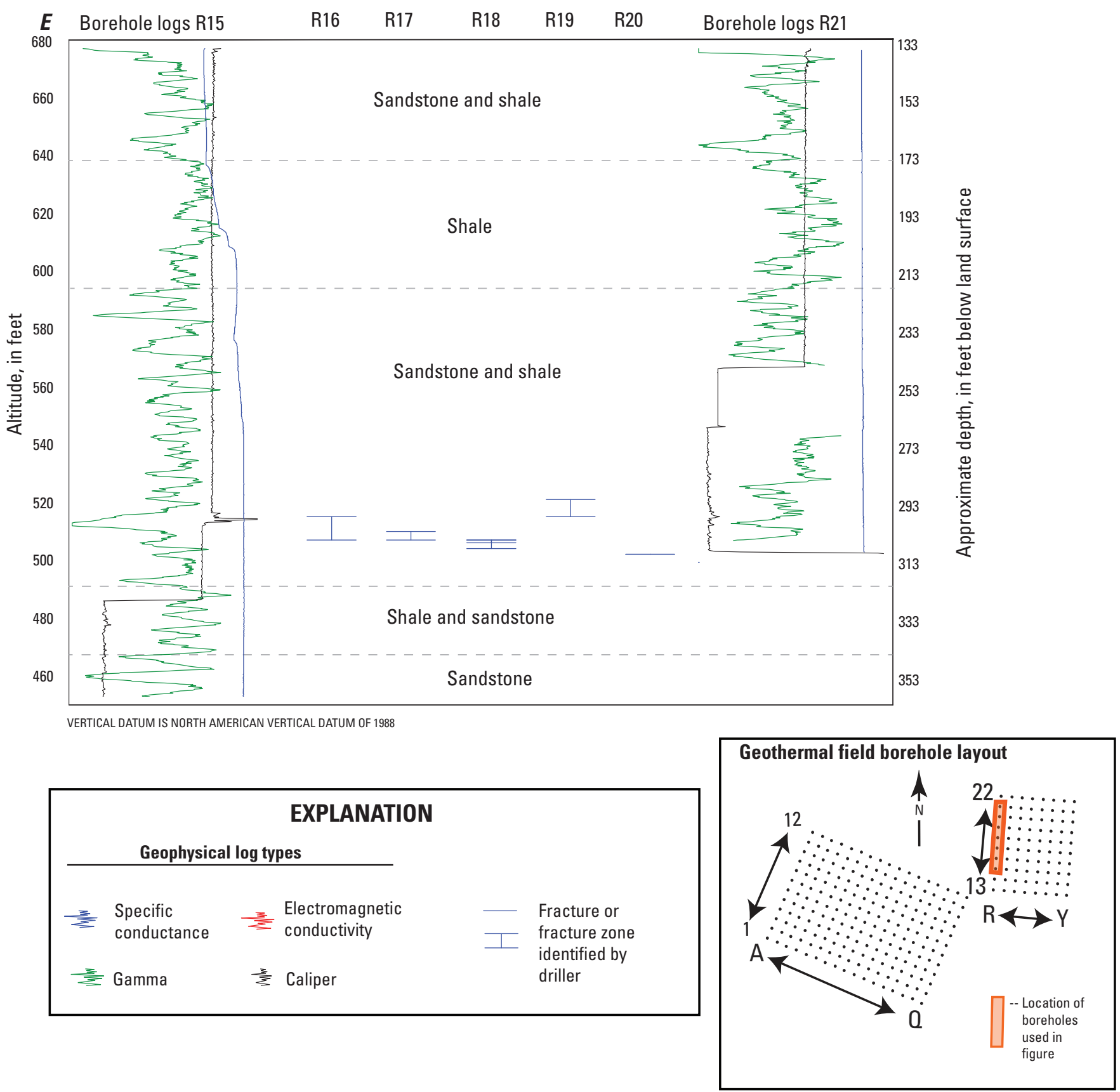

Figure 9. Gamma, caliper, electromagnetic-conductivity, and specific-conductance logs, showing relative log response, and saline water-bearing fractured zones reported by the driller in selected boreholes at the Owego-Apalachin Elementary School geothermal fields, Tioga County, New York: $A$, borehole $\mathrm{A} 1$ to borehole A9; $B$, borehole 01 to borehole 010; $C$, borehole $\mathrm{A} 9$ to borehole $\mathrm{K} 9$; $D$, borehole $\mathrm{K} 9$ to borehole 010 ; $E$, borehole R15 to borehole R21; and $F$, borehole R15 to borehole Y17.-Continued 


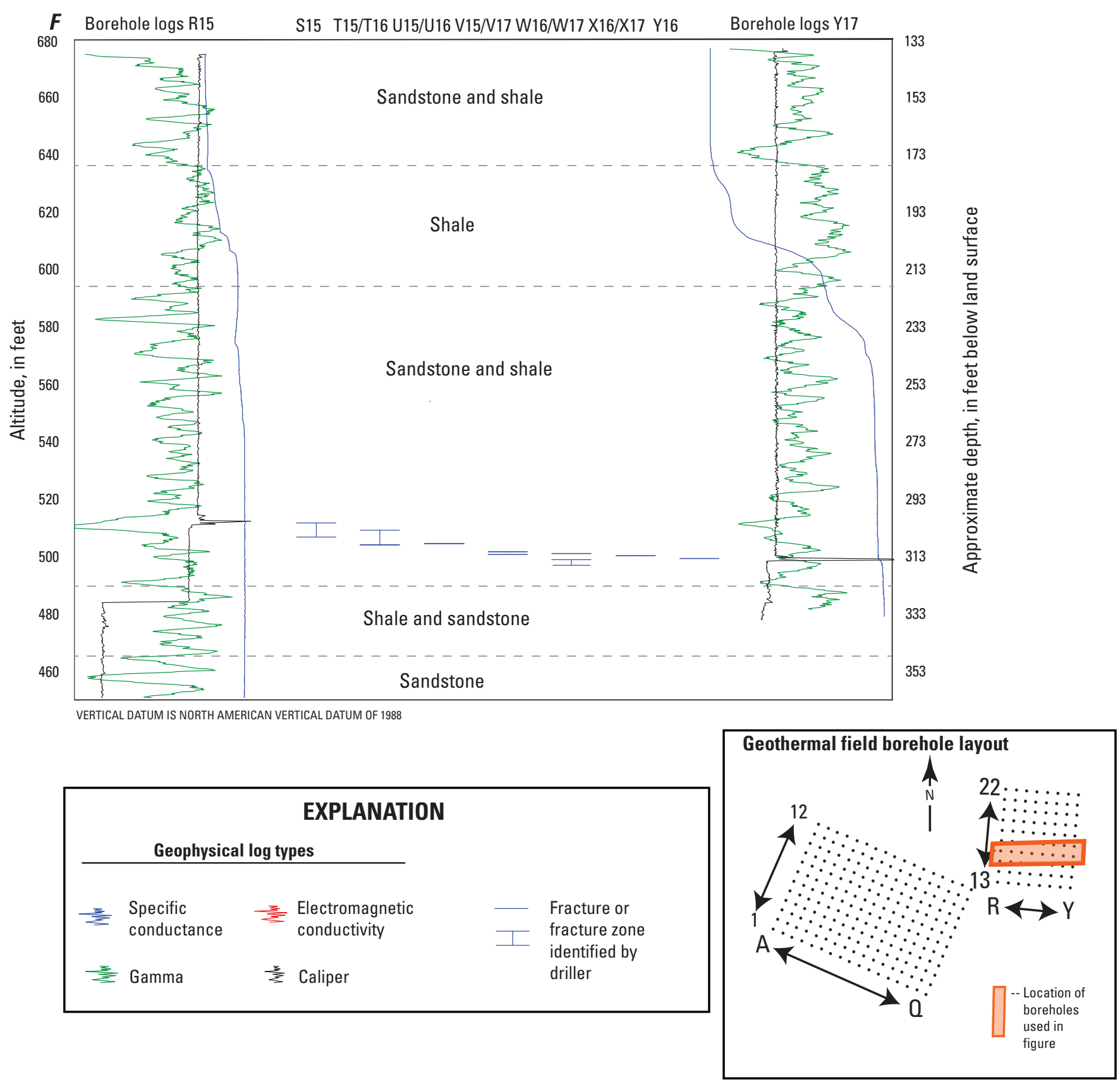

Figure 9. Gamma, caliper, electromagnetic-conductivity, and specific-conductance logs, showing relative log response, and saline water-bearing fractured zones reported by the driller in selected boreholes at the Owego-Apalachin Elementary School geothermal fields, Tioga County, New York: $A$, borehole $\mathrm{A} 1$ to borehole A9; $B$, borehole 01 to borehole $010 ; C$, borehole $\mathrm{A} 9$ to borehole $\mathrm{K} 9$; $D$, borehole $\mathrm{K} 9$ to borehole $\mathrm{Q10}$; $E$, borehole R15 to borehole R21; and $F$, borehole R15 to borehole Y17. —Continued 
Appendix 1. Video of Local News Report about Methane Fire During Drilling of Borehole A9 at the Owego-Apalachin Elementary School Geothermal Fields, Tioga County, New York

[Available separately at http://dx.doi.org/10.3133/sir20155155]

Appendix 2. Location, Construction, and Hydrogeologic Information for Selected Boreholes and Wells at and near the Owego-Apalachin Elementary School Geothermal Fields, Tioga County, New York

[Available separately at http://dx.doi.org/10.3133/sir20155155]

Appendix 3. Field and Laboratory Chemical Analyses of Water and Gas Samples from Boreholes A9 and 01 at the Owego-Apalachin Elementary School Geothermal Fields, Tioga County, New York

[Available separately at http://dx.doi.org/10.3133/sir20155155]

Appendix 4. Video of the Unloading of Methane Gas and Water from Borehole A12 at the Owego-Apalachin Elementary School Geothermal Fields, Tioga County, New York 

For additional information write to:

Director, New York Water Science Center

U.S. Geological Survey

425 Jordan Road

Troy, NY 12180-8349

dc_ny@usgs.gov

Information requests:

(518) 285-5602

or visit our Web site at:

http://ny.water.usgs.gov

Publishing support by:

The Pembroke and West Trenton Publishing Service Centers. 


\section{$\frac{\mathbb{2}}{3}$}

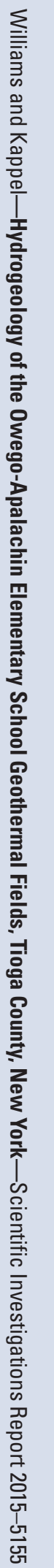

ISSN 2328-0328 (online) 